MICHIGAN RETIREMENT AND DISABILITY RESEARCH CENTER UNIVERSITY OF MICHIGAN

Promoting research on retirement, disability, and Social Security policy

\title{
Subjective Expectations, Social Security Benefits, and the Optimal Path to Retirement
}

María J. Prados and Arie Kapteyn

MRDRC WP 2019-405

UM19-06 


\title{
Subjective Expectations, Social Security Benefits, and the Optimal Path to Retirement
}

\author{
María J. Prados \\ University of Southern California
}

\author{
Arie Kapteyn \\ University of Southern California and NBER
}

\section{November 2019}

Michigan Retirement and Disability Research Center, University of Michigan, P.O. Box 1248. Ann Arbor, Ml 48104, mrdrc.isr.umich.edu, (734) 615-0422

\section{Acknowledgements}

The research reported herein was performed pursuant to a grant from the U.S. Social Security Administration (SSA) funded as part of the Retirement Research Consortium through the University of Michigan Retirement Research Center Award RDR18000002. The opinions and conclusions expressed are solely those of the author(s) and do not represent the opinions or policy of SSA or any agency of the federal government. Neither the United States government nor any agency thereof, nor any of their employees, makes any warranty, express or implied, or assumes any legal liability or responsibility for the accuracy, completeness, or usefulness of the contents of this report. Reference herein to any specific commercial product, process or service by trade name, trademark, manufacturer, or otherwise does not necessarily constitute or imply endorsement, recommendation or favoring by the United States government or any agency thereof. The project described in this paper relies on data from survey(s) administered by the Understanding America Study, which is maintained by the Center for Economic and Social Research (CESR) at the University of Southern California. The content and views expressed in this paper are solely the responsibility of the authors and do not necessarily represent the official views of USC or UAS or those of the funders or the official views of the National Institutes of Health.

\section{Regents of the University of Michigan}

Jordan B. Acker; Huntington Woods; Michael J. Behm, Grand Blanc; Mark J. Bernstein, Ann Arbor; Paul W. Brown, Ann Arbor; Shauna Ryder Diggs, Grosse Pointe; Denise llitch, Bingham Farms; Ron Weiser, Ann Arbor; Katherine E. White, Ann Arbor; Mark S. Schlissel, ex officio 


\title{
Subjective Expectations, Social Security Benefits, and the Optimal Path to Retirement
}

\begin{abstract}
Americans face the challenges of retirement with varying degrees of preparation. Evidence indicates that that many individuals may not be making the best possible choices with respect to their Social Security and retirement savings. We assess the subjective expectations of nonretirees and find that they have sizable biases and uncertainty about future retirement benefits. This uncertainty and the level of subjective expectations can affect workers' wealth accumulation and retirement readiness. We build on these observations and combine unique survey data with a life-cycle optimization model to measure the role of Social Security literacy, subjective expectations about retirement benefits, and behavioral traits as determinants of lifecycle savings decisions and welfare. The goal of this project is to better understand the role of retirement expectations as determinants of savings decisions and retirement income. We forecast future benefits and measure the bias in expectations. We find heterogeneity in the direction of the expectation bias: Men and those with low levels of uncertainty about retirement benefits are less likely to overestimate their future retirement benefits, hence are more likely to save more and reach retirement better prepared. We find that these biases in subjective expectations translate into suboptimal asset accumulation and welfare losses.
\end{abstract}

\section{Citation}

Prados, María J., and Arie Kapteyn. 2019. "Subjective Expectations, Social Security Benefits, and the Optimal Path to Retirement." Ann Arbor, MI. University of Michigan Retirement and Disability Research Center (MRDRC) Working Paper; MRDRC WP 2019-405.

https://mrdrc.isr.umich.edu/publications/papers/pdf/wp405.pdf

\section{Authors' acknowledgements}

We are grateful to Joanne Yoong for key insights into the survey development and advice, to Juan Saavedra, Dan Benjamin and participants at the Econometric Society Summer Meeting for helpful comments. We thank Brian Finley for his research assistance. 


\section{Introduction}

The period after retirement typically poses economic risks and challenges that differ from those faced during working life. Americans reach retirement with varying degrees of preparation and, thus, government-provided social insurance plays an important role, especially when private pensions and personal savings fall short. However, research shows that retirement security is a major concern for many Americans: In 2014, the Employee Benefit Research Institute's Retirement Confidence Survey reported that only $18 \%$ of workers were confident about having enough money for a comfortable retirement while $36 \%$ of respondents reported total savings or investments under $\$ 1,000$.

Poterba (2014) points out the large differences in retirement finances between the upper and lower strata of the income distribution. There is a steep gradient in the portfolio composition of individuals' assets at retirement age. In the data from the Current Population Survey, only $5.4 \%$ of the individuals 65 and older in the lowest quartile of income distribution receive pension income, and $26.4 \%$ of them received asset income in 2013. These numbers are $52 \%$ and $57 \%$ respectively for individuals 65 and older in the third quartile of the income distribution. According to these data, Social Security benefits make up $85 \%$ of individual income for those at the bottom quartile of the distribution.

A key pillar of retirement security in the United States is the Social Security system and, therefore, understanding Social Security benefits is a key component of optimal financial planning. Yet there is wide-spread confusion about claiming ages, how 
benefits are calculated, and entitlements, and many nonretirees are not confident about receiving the level of Social Security benefits they currently are entitled to when they retire (Yoong et al. 2015). This lack of knowledge or biased subjective expectations could lead to suboptimal savings and retirement choices. Moreover, behavioral traits (such as an overall propensity to plan, or lack thereof) and their interaction with the choice environment can affect planning, potentially exacerbating differences in the ability to correctly make decisions involving the complex rules behind Social Security benefit determination (Binswanger and Carman 2012).

This paper highlights the characteristics and relevance of expectations about Social Security retirement benefits and the importance of behavioral aspects of planning for retirement. For this, we developed a survey to measure expectations and their influence on retirement and retirement preparation. We use the biases measured from the survey to study the role of expectations about retirement as a determinant of savings decisions and retirement income. We contrast the ex-post experience of current retirees to the expectations of nonretirees. We find that there is sizable uncertainty about future retirement benefits among nonretirees. This uncertainty and the level of subjective expectations are correlated with the accumulation of wealth by workers, which is in line with the presence of precautionary savings. We find some heterogeneity in the direction of the expectation bias: Older workers and men are less likely to overestimate their future retirement benefits. But we find no significant difference by educational attainment on the probability of overestimating benefits.

Lusardi et al. (2017) find that endogenous financial knowledge accumulation has the potential to account for a large proportion of wealth inequality. This happens as high 
earners find it optimal to accumulate more financial knowledge than low earners, and this boosts their wealth accumulation even further. Scholz et al. (2006) assess the optimality of wealth accumulation using a stochastic life-cycle model with rational expectations about future earnings and benefits using HRS data from 1992. They find that most people in 2005 had achieved their savings targets according to their model.

We build on the aforementioned observations to develop a quantitative analysis that combines the unique survey data we collected with a standard life-cycle optimization model to measure the role of Social Security literacy and subjective expectations about retirement benefits as determinants of life-cycle consumption and savings decisions. We use our survey data to inform a standard life-cycle optimization model augmented with subjective expectations to predict individual savings and consumption paths. We compare such predictions with those that would result from the often-made assumption of perfect information or rational expectations. We compare the welfare resulting from different savings paths, and assess the relative importance of subjective expectations and behavioral factors in determining savings dynamics and welfare.

Related papers in the literature are Scholz et al. (2006) for the case of rational expectations and Benítez-Silva et al. (2009) for subjective expectations. A separate literature has focused on other determinants of savings, like medical expenditures and bequest motives, ${ }^{1}$ but we abstract from those dimensions. The main features of our model are standard in this literature, such as allowing for uninsurable risky earnings.

\footnotetext{
${ }^{1}$ See Laitner and Juster (1996), De Nardi et al. (2010), Lockwood (2018) and De Nardi and Yang (2014).
} 
Our contribution is to include a set of individual subjective expectations, which allows us to measure the importance of expectations biases. This approach allows us to measure the welfare consequences of biased beliefs and behavioral factors, as well as the insurance effects of Social Security benefits. Furthermore, we compare the respondents' actual wealth positions and earnings paths to those generated by the perfect information model and by the model that includes elicited subjective expectations.

Section 2 explains our data and the methodology we follow to elicit subjective expectations in our survey. Section 3 shows the empirical findings. Section 4 introduces the model and presents the results from our quantitative analysis. Section 5 concludes.

\section{Data}

\subsection{The Understanding America Study}

Our main data source for all the economic, demographic, and subjective expectations variables is the Understanding America Study (UAS). The UAS is an internet panel study, managed by the University of Southern California, of currently more than 8,000 households representing the entire U.S. ${ }^{2}$

The UAS consists of module surveys that can be linked to each other. It collects a wide range of variables, including household demographics, knowledge and attitudes

2 The panel was recruited by address-based sampling, and anyone willing to participate yet lacking a computer or internet access has been provided a tablet and broadband Internet. Sampling weights for the UAS are generated in such a way that the weighted distributions of specific sociodemographic variables in the survey sample match their population counterparts as derived from the Current Population Survey. 
of retirement planning, understanding of Social Security, financial literacy, numeracy, cognition, and personality traits. The module on asset and income data in the UAS is modeled after the Health and Retirement Study, and respondents complete it biennially. Two key advantages of the UAS are the ability to leverage available past surveys and the ability to introduce new surveys that take advantage of the online mode.

We supplemented our expectations survey with other data collected in the UAS, including household demographics, attitudes and perceptions of retirement planning in general, understanding of Social Security eligibility and entitlements, and qualitative views on expectations of Social Security, assets, and income.

\subsubsection{Sample}

For our analysis, we consider nondisabled workers and retirees. ${ }^{3}$ This leaves us with a sample of 4,632 nondisabled adults 20 and older. The sample means are shown in Table 1.

Table 2 shows the number of nondisabled individuals 20 and older in each age and group-education category cell in the survey. For most of our analysis, we focus on individuals 30 or older who are neither disabled nor retired. This reduces the sample to 3,099 respondents. Of those, we have information on Social Security benefit expectations for 2,162 respondents, and the earnings history for 1,337 of them.

\footnotetext{
${ }^{3}$ The survey (UAS72: https://uasdata.usc.edu/index.php) was in the field between January 9 and November 3, 2017. During this period, 5479 UAS panel members were invited to take the survey, of whom 5,109 respondents completed the survey, for a response rate of $93.2 \%$.
} 
Table 1: Survey sample means

\begin{tabular}{ll}
\hline Characteristic & Mean \\
\hline Male & $42.9 \%$ \\
Less than high & $4.9 \%$ \\
school & $56.4 \%$ \\
High school/GED/AD & $38.6 \%$ \\
College & $9.2 \%$ \\
Black & $10.2 \%$ \\
Hispanic/Latino & $3.4 \%$ \\
Asian & 48.8 \\
Average age & $62.5 \%$ \\
Married & $19.5 \%$ \\
Retired & \\
\hline
\end{tabular}

Source: UAS 72

Table 2: Sample size by educational attainment and age group

\begin{tabular}{lllll}
\hline Age & $\begin{array}{l}\text { Less than } \\
\text { high } \\
\text { school }\end{array}$ & $\begin{array}{l}\text { High } \\
\text { school, } \\
\text { GED, AD }\end{array}$ & College & Total \\
\hline $\mathbf{2 0 - 2 9}$ & 51 & 343 & 156 & 550 \\
$\mathbf{3 0 - 3 9}$ & 62 & 512 & 420 & 994 \\
$\mathbf{4 0 - 4 9}$ & 37 & 478 & 374 & 889 \\
$\mathbf{5 0 - 5 9}$ & 32 & 588 & 318 & 938 \\
$\mathbf{6 0 - 6 9}$ & 26 & 459 & 323 & 808 \\
$\mathbf{7 0 - 7 9}$ & 17 & 197 & 150 & 364 \\
$\mathbf{8 0 +}$ & 5 & 45 & 39 & 89 \\
\hline Total & 230 & 2,622 & 1,780 & 4,632 \\
\hline
\end{tabular}

Source: UAS 72

\subsubsection{Standard variables in UAS}

We supplemented our survey with data from other UAS modules. The UAS

collects income data from all sources and several categories of assets every two years, using the same survey instrument as the Health and Retirement Study. So far, these surveys collected data for 2015 and 2017 . Therefore, two waves of income and assets data are available for most respondents. 


\subsubsection{Income and wealth measures}

In retirement, households have three main sources of income: Social Security benefits, their own (private) savings, and employer-provided pensions. To study the degree of retirement readiness in our sample, we need accurate measures of these components. The UAS fields two modules designed after the Health and Retirement Study assets and income modules, which collect comprehensive and detailed data on income and wealth components.

Net worth (private savings) is a comprehensive measure that includes housing assets less liabilities, business assets less liabilities, checking and saving accounts, stocks, bonds, mutual funds, retirement accounts including defined-contribution pensions, certificates of deposit, the cash value of whole life insurance, and other assets, less credit card debt and other liabilities. It excludes defined-benefit pension wealth, Social Security wealth, and future earnings. The concept of wealth is similar (and in many cases identical) to those used in other studies of wealth and saving adequacy. ${ }^{4}$

We include labor earnings from employment, including self-employment, in our analysis. We deflate nominal past reported income to year 2010 dollars using the Consumer Price Index.

\subsubsection{Financial literacy}

For financial literacy, we use the five questions about basic financial concepts questions developed by Lusardi and Mitchell (2007) to compute a financial literacy

\footnotetext{
${ }^{4}$ In our analysis, we winsorize the wealth variables using a $99 \%$ cut.
} 
score. The financial literacy score is the number of correct answers, thus it takes values between zero and five. The basic financial literacy questions included in UAS are the following:

1. Numeracy

Suppose you had $\$ 100$ in a savings account and the interest rate was $2 \%$ per year. After 5 years, how much do you think you would have in the account if you left the money to grow? (i) More than \$102; (ii) Exactly \$102; (iii) Less than $\$ 102$; (iv) Do not know (DK); (v) Refuse.

2. Compound Interest

Suppose you had $\$ 100$ in a savings account and the interest rate is $20 \%$ per year and you never withdraw money or interest payments. After 5 years, how much would you have on this account in total? (i) More than \$200; (ii) Exactly \$200; (iii) Less than \$200; (iv) DK; (v) Refuse.

3. Inflation Imagine that the interest rate on your savings account was $1 \%$ per year and inflation was $2 \%$ per year. After 1 year, how much would you be able to buy with the money in this account? (i) More than today; (ii) Exactly the same; (iii) Less than today; (iv) DK; (v) Refuse.

4. Time Value of Money Assume a friend inherits $\$ 10,000$ today and his sibling inherits $\$ 10,0003$ years from now. Who is richer because of the inheritance? (i) My friend; (ii) His sibling; (iii) They are equally rich; (iv) DK; (v) Refuse. 


\section{Money Illusion}

Suppose that in the year 2010, your income has doubled and prices of all goods have doubled too. In 2010, how much will you be able to buy with your income?

(i) More than today; (ii) The same; (iii) Less than today; (iv) DK; (v) Refuse.

\subsubsection{Other variables}

Other variables collected include the age at which the respondents expect to claim Social Security benefits, and whether they expect that the Social Security system will be able to pay their promised benefits in the future.

\subsubsection{Specific variables from the custom UAS survey}

The UAS survey module we designed for this project elicits subjective distributions of future labor earnings, Social Security retirement benefits, defined benefit plan amounts, balances in other retirement plans, and retirement age. It also includes the following key aspects: planning strategies (rule of thumb, planners, unsystematic), earnings history, and retirement experience versus preretirement expectations (for retirees only).

\subsubsection{Elicitation of subjective expectations}

For the survey respondents who are not retired, we elicit their subjective expectations about several variables of interest: Social Security retirement benefits, defined benefit retirement plans, future earnings, other assets (including balances in defined contribution retirement accounts), medical expenditures in old age, and age at retirement. For all the monetary variables we elicit a distribution of expected values, in a fashion similar to Dominitz and Manski (2006). 
We elicit subjective expectations about Social Security retirement benefits $y_{i}$ in the following way: We ask about the highest monthly benefit the individual might receive $\left(Y_{\text {high }}\right)$, and about the lowest monthly benefit the individual might receive $\left(Y_{\text {low }}\right)$. Then, we divide this support into five equal intervals and ask respondents the chances that their benefits will fall within each of the five intervals. In this way we obtain the subjective distribution $B_{\text {in }}=\operatorname{Pr}\left(y_{i}<Y_{\text {in }} \mid \Omega_{i}\right)$ for individual $i$ with information set $\Omega_{i}$, where $Y_{\text {in }}, n=1 \ldots 5$ are the thresholds based on $Y_{\text {high }}$ and $Y_{\text {low }}$.

We implemented this elicitation using the visual format in Delavande and Rohwedder (2008). The visual format elicits information on individuals' subjective probability distributions about their future variables of interest in a way that mimics the density function of their subjective beliefs. An example of the screen seen by the respondent is given in Figure 1. Participants are asked to place balls in each bin, proportional to the chances of each possible outcome. In a preliminary experiment, we compared different elicitation methods and found this one to be the most reliable. ${ }^{5}$

In all questions that refer to the future value of some variable, we ask participants to think about it in real terms: "as if a dollar in the future were worth the same as a dollar today." When the question is about the monetary value of something in the past, like earnings history, we ask about it in nominal terms.

\footnotetext{
${ }^{5}$ In Prados and Kapteyn (2016), we validated this method against alternatives and found that this visual format was slightly faster and not as prone to errors among the less educated.
} 


\section{Figure 1: Visual elicitation of subjective distribution for future Social Security benefits}

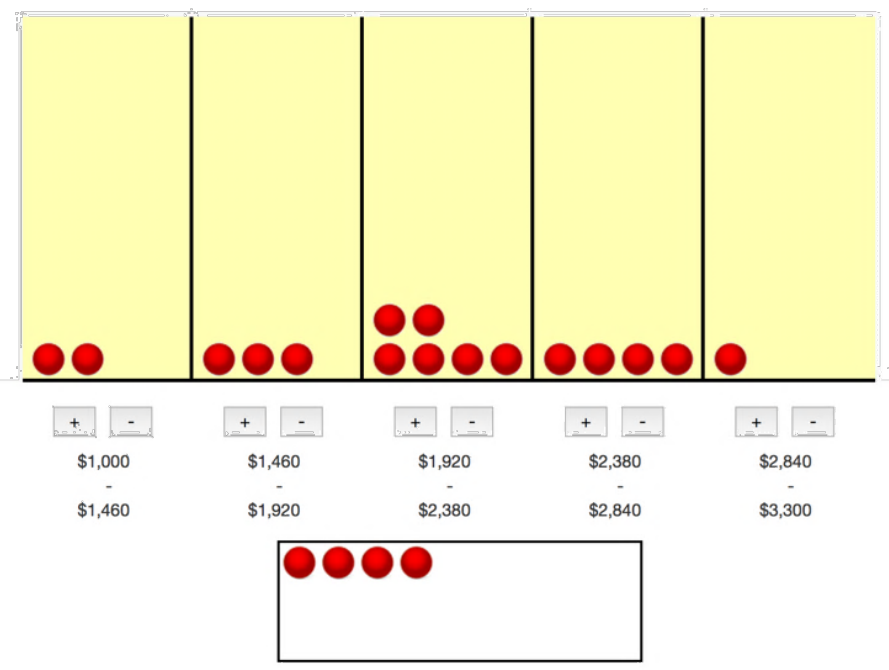

Note: This figure shows an example of the screen a survey participant sees. In this case, the minimum retirement benefit the participant expects to obtain is $\$ 1,000$, and the maximum is $\$ 3,300$. The participant has placed 16 balls in bins according to his subjective probabilities of retirement benefits ending up in each of the intervals, and still has four balls to allocate. The participant cannot move on to the next question before allocating all 20 balls.

To elicit expectations about future earnings, for most participants, we divided the future horizon between the time of the survey and their expected retirement in two periods. We asked them to provide the maximum and minimum expected earnings for each period. We divided that support in five bins and asked them to assign a probability to each bin. For participants who expected to retire within the next five years, we only asked about one future period between the survey date and retirement. We asked them to report their expected future earnings in current dollars, not accounting for future inflation. 


\subsubsection{Earnings history}

To elicit past earnings, we divided the working history of each individual in a number of time periods. Depending on how long the respondents have been participating in the labor force, they were asked about their average past earnings over their work history divided in one, two, or three periods. They were asked about their past earnings in nominal terms, as is standard practice.

\subsubsection{Planning Types}

We use the answers to four questions to categorize individuals to three types according to their attitudes toward planning, following Binswanger and Carman (2012). The planning types are:

- Unsystematic: if subject reports no planning and no rule of thumb for savings;

- Planner. if subject has a forward-looking plan for savings;

- Rule of thumb: if subject follows a simple rule of thumb to determine their savings.

\subsection{Auxiliary data}

We use the Panel Study of Income Dynamics (PSID) to estimate a model of earnings and forecast future earnings paths for our UAS sample. We use the Consumer Price Index series from the Bureau of Labor and Statistics to deflate nominal earnings.

\section{Empirical Evidence}

\subsection{Measures of expectations and retirement adequacy, current retirees}

Part of the motivation for this study comes from evidence indicating that current retirees are not satisfied about aspects of their retirement. We survey current retirees in 
our sample about their present retirement experience. We analyze the kind of regrets they experience after retirement. Table 3 shows there is sizable heterogeneity in the degree of retirement readiness current retirees felt at the time of their retirement.

Table 3: Financial readiness for retirement, current retirees

\begin{tabular}{ll}
\hline How well prepared financially were you for & Percent \\
retirement? & \\
\hline Very well prepared & $28.2 \%$ \\
Somewhat well prepared & $42 \%$ \\
Not too prepared & $18.3 \%$ \\
Not prepared at all & $11.5 \%$ \\
\hline
\end{tabular}

Note: The number of observations for this variable is 950 . Source: UAS

Of the retiree subsample in the survey, $43 \%$ said they would want to be able to change something about their current retirement. Individuals with high school are more likely to want to change how retirement is going than college graduates, as shown in Figure 2.

Figure 2: Fraction of respondents in the retiree subsample who say they would want something different about their retirement

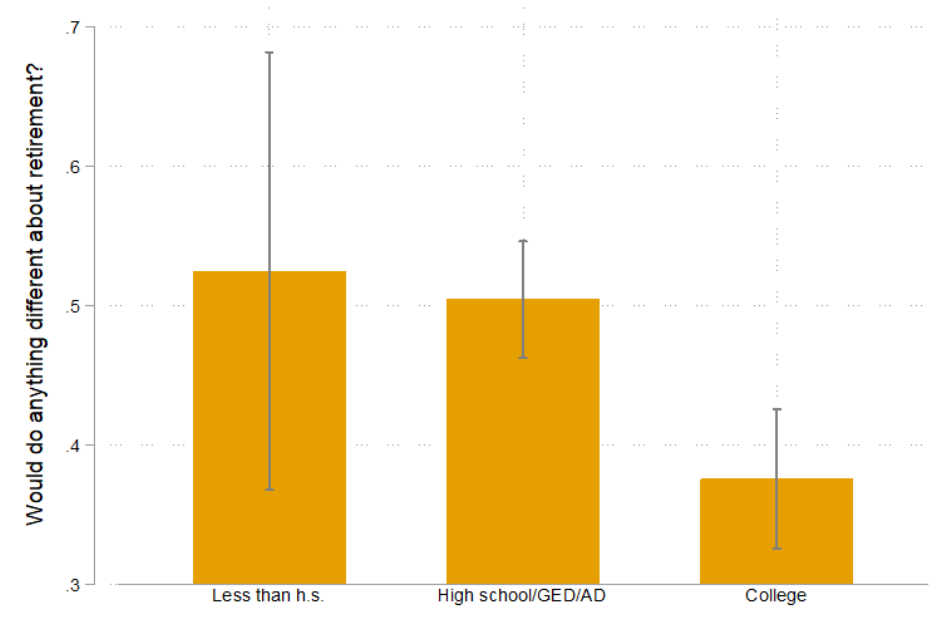

Note: Proportion by educational attainment. 95\% confidence intervals shown. Source: UAS 
When looking at the aspects they would like to be able to change, $22 \%$ of current retirees in our sample regret claiming Social Security benefits when they did ( $20 \%$ of retirees would have liked to claim later). Figure 3 shows several aspects of retirement that current retirees would have liked to change. The main aspects have to do with income during retirement, being better prepared, and retiring later. Thirty-seven percent of the respondents in this subsample would have liked to retire later, but only half of those who would have liked to retire later would have also preferred to claim their benefits later.

\section{Figure 3: What would people like to change about their own retirement?}

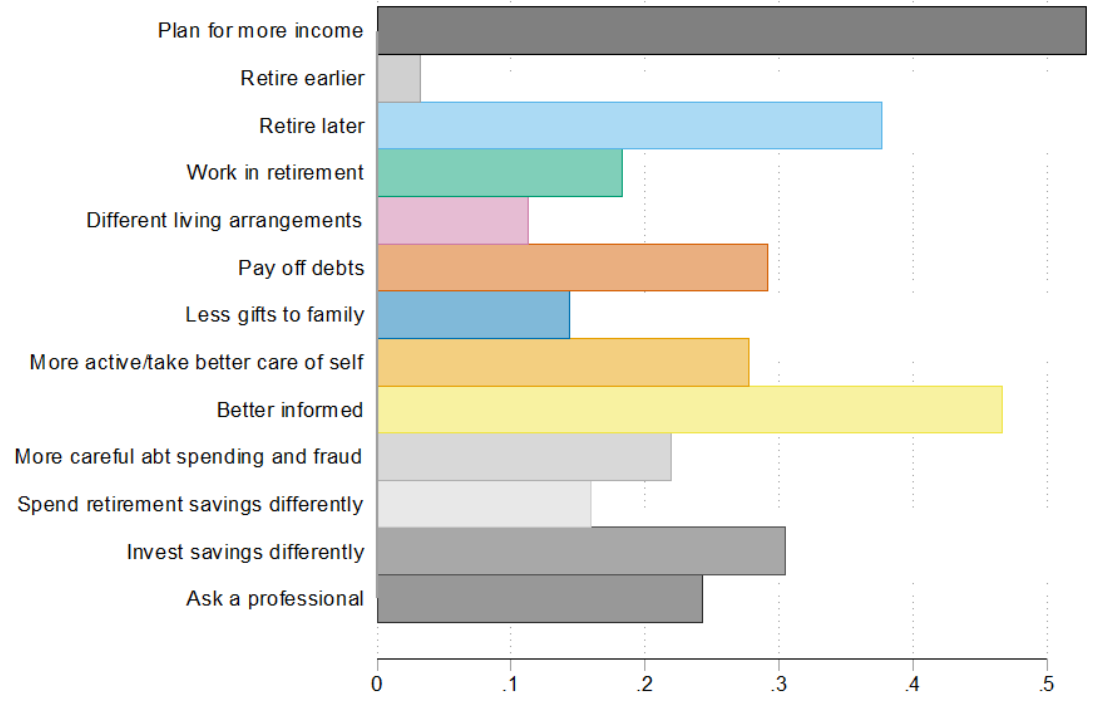

Note: Proportion of retirees who would change each retirement aspect. Source: UAS, retiree subsample

Some retirees acknowledge they had biased expectations - before retiring about the retirement benefits they would receive. In fact, $21.4 \%$ of the respondents said 
the benefits they received at retirement were substantially different than what they expected to receive. As Figure 4 shows, most of them had expected to receive more.

Figure 4: Distribution of expectation error (monthly amount), among current retirees

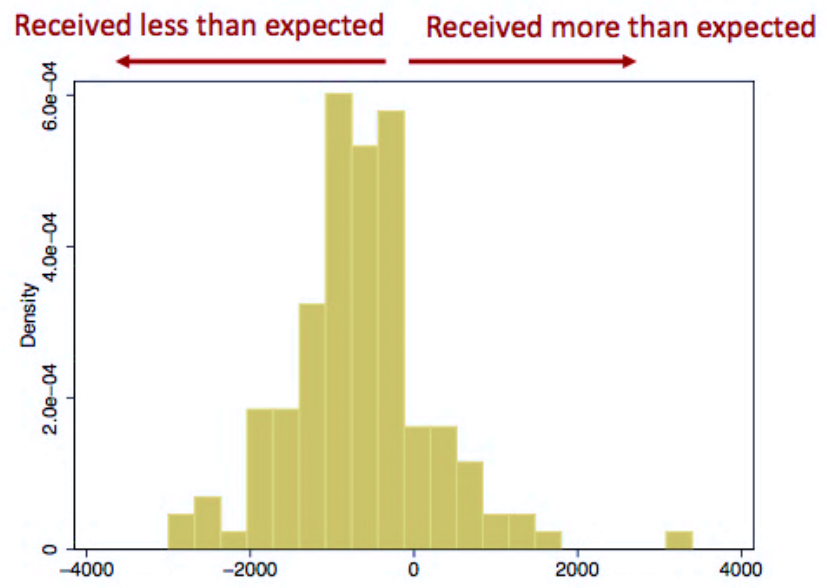

Note: The ex-post error is defined as the actual monthly amount of Social Security retirement benefits received when they started claiming minus the benefit they had expected to receive. Therefore, negative values indicate the benefits received were lower than expected.

Source: UAS, retiree subsample

The size of these errors varies with the educational attainment of retirees, as Figure 5 shows. Those with lower educational attainment are more likely to be receiving benefits substantially lower than what they expected. High school and college degree holders seem to be mostly receiving what they were expecting. 


\section{Figure 5: Difference between expected and received SS benefits (as percent of received)}

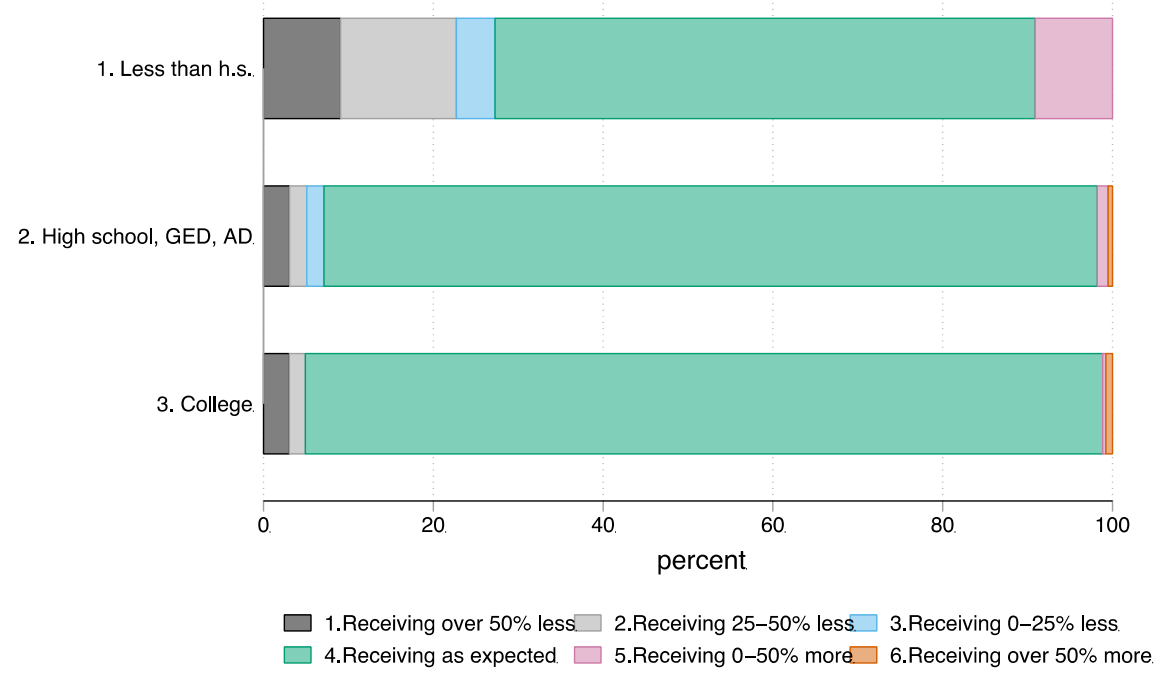

Source: UAS, retiree subsample

\subsection{Factors that may affect retirement readiness}

Social Security benefits are an important component of financial resources during retirement and a major source of income for many individuals. Yet, many individuals display high levels of uncertainty about their future retirement benefits, which may affect their retirement readiness. More than $50 \%$ of our sample of nonretirees declare they do not have a good estimate of their future Social Security benefits. Additionally, at least $12 \%$ of those who expect to retire by age 65 assign a positive probability to receiving benefits (in real terms) above the current legal maximum.

We asked nonretired participants how well they would say they know the value of their future retirement benefits. They had the following options: $i$. "I know for certain how much they will be" (9\% of respondents); ii. "I have a guess/estimate" (41.9\%); iii. "I have no idea how much they will be" (49.1\%). Figure 6 shows the fraction in each category 
across age groups. The perceived uncertainty about future retirement benefits decreases with age.

Figure 6: Knowledge about future Social Security retirement benefits (self-reported)

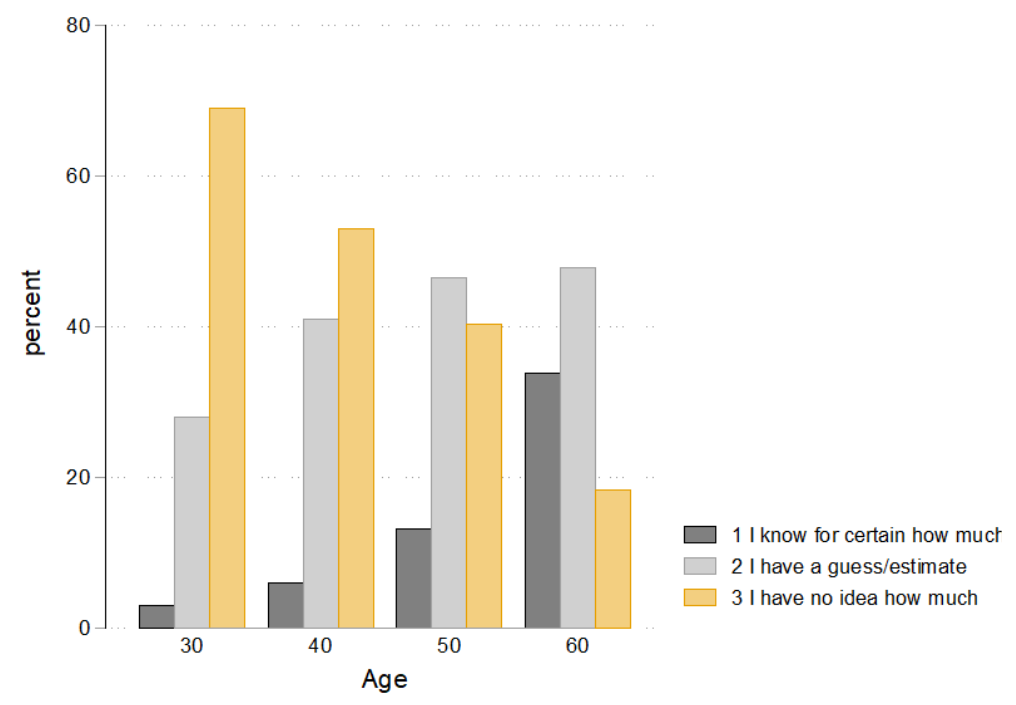

Note: Percent of each age group according to what they know about their future Social Security benefits. Source: UAS

There is heterogeneity in behavioral factors that may be relevant to retirement readiness, such as propensity to plan and financial literacy. Figure 7 shows the prevalence of different attitudes toward financial planning, as defined in Section 2.1.3.3. Most individuals fall within the categories of unsystematic savings or they follow a rule of thumb to determine their savings. Around $30 \%$ of the sample report having determined their needs and planned accordingly. Older and more educated individuals are more likely to be systematic planners. The left panel of Figure 7 shows that older individuals are more likely to be systematic planners and less likely to have an unsystematic approach to their financial planning than younger individuals. The right 
panel of Figure 7 shows that most individuals with high school degree or less are not systematic about their financial planning, but the unsystematic planners are the minority among individuals with a college degree. Individuals with a college degree are more likely to be either planners or to follow a rule of thumb than individuals with lower educational attainment.

Figure 7: Prevalence of planning for retirement by age (left) and educational attainment (right), nonretirees
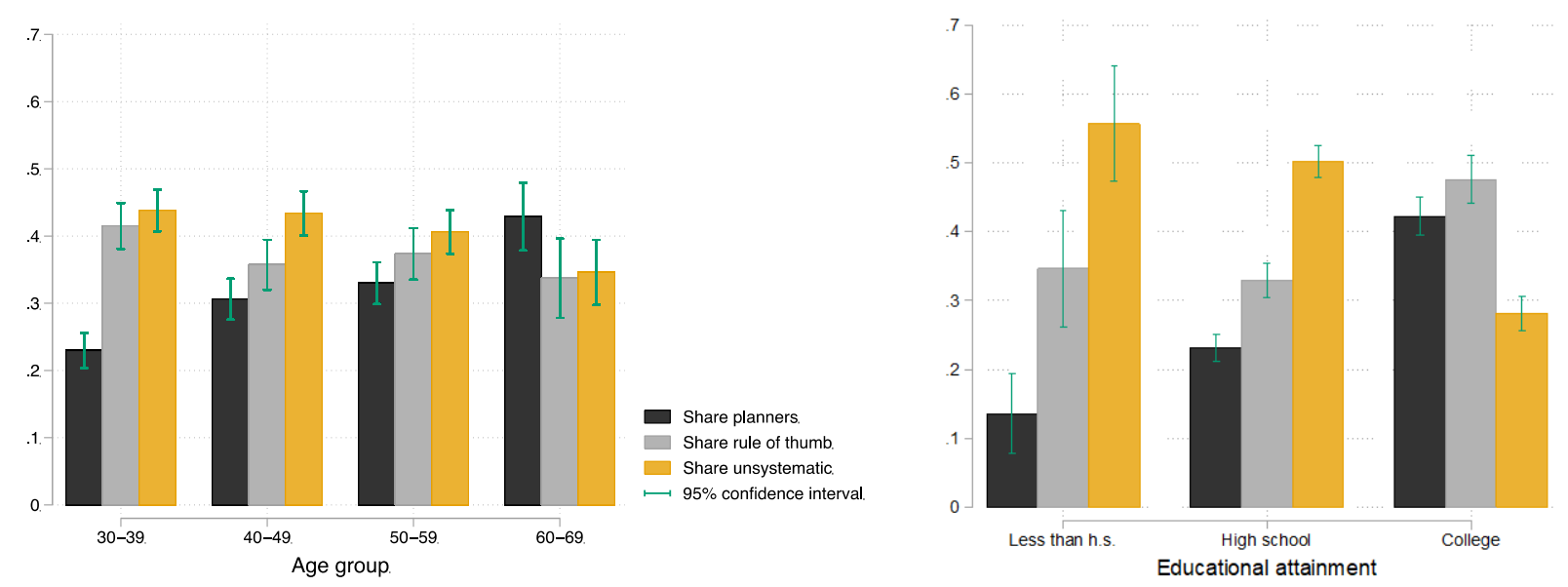

Source: UAS

Figure 8 presents the average financial literacy score, defined in Section 2.1.2.2. A similar pattern as seen for financial planning applies when it comes to financial literacy. Older individuals and those with higher levels of educational attainment fare better when it comes to understanding basic financial literacy concepts than younger or less educated ones. 
Figure 8: Average financial literacy score by age (left) and educational attainment (right), nonretirees
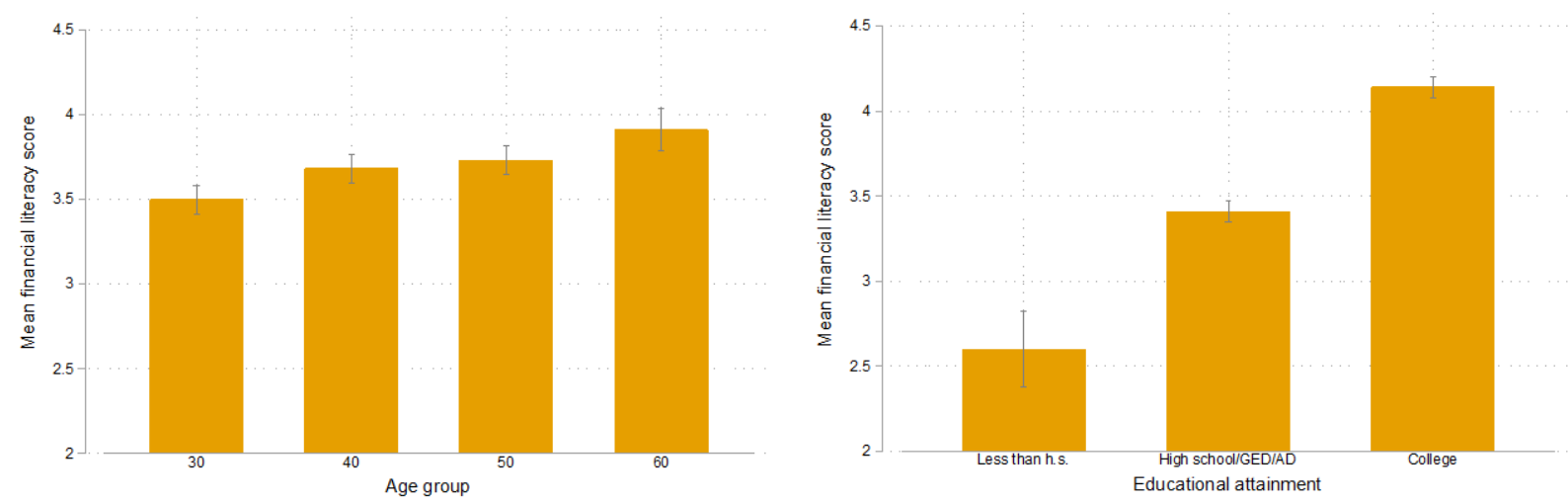

Note: The minimum financial literacy score is 0 and the maximum is 5 .

Source: UAS

\section{$\underline{3.2 .1 \text { Subjective expectations }}$}

Using the elicited subjective distribution of monthly amounts of future Social Security benefits, we compute distributional moments, measures of uncertainty, expectation bias, and the probability of overestimating future benefits. For this, unless the individual probability distribution function elicited is constant for each bin or degenerate at one value, we assume subjective expectations follow a lognormal distribution at the individual level. ${ }^{6}$ Like Dominitz and Manski (1997), we use a leastsquares criterion to fit person-specific lognormal distributions to the answers of the respondents. For each individual distribution, we obtain the mean and standard deviation, and compute the inter-quartile ratio $\left(I Q R=p_{75}-p_{25}\right)$.

${ }^{6}$ Of the nonretired sample ages 30 to $70,4.5 \%$ provided a constant probability for each bin of their benefits expectations, while $3.5 \%$ of this sample gave a degenerate distribution for their expected monthly benefits. 
Table 4 shows the average mean and IQR of the distributions of expected monthly Social Security benefits by characteristics of nonretirees. The means of the distributions of benefits follow an expected pattern as higher income individuals (college, married, men) expect higher levels of benefits.

Table 4: Average mean and IQR of subjective Social Security benefit distributions, by characteristics of the subsample of nonretirees

\begin{tabular}{lll}
\hline & Mean & IQR \\
\hline Total sample & 1470.40 & 207.27 \\
Female & 1312.05 & 191.43 \\
Male & 1662.35 & 225.88 \\
Not married & 1397.63 & 203.51 \\
Married & 1507.12 & 209.16 \\
Less than high & 1017.86 & 250.26 \\
school & 1301.81 & 184.34 \\
High school & 1697.86 & 231.61 \\
College &
\end{tabular}

Note: The IQR is the difference between the percentiles 75 and 25 of the distribution.

We use the IQR as an approximate measure of an individual's level of uncertainty about their future retirement benefits. Figure 9 shows that this uncertainty declines with age. There is substantial variation in the IQR of the subjective distributions of retirement benefits, with many individuals displaying high levels of uncertainty about their future benefits. 
Figure 9: Average inter-quartile range (IQR $=p_{75}-p_{25}$ of monthly benefits distribution), by age group

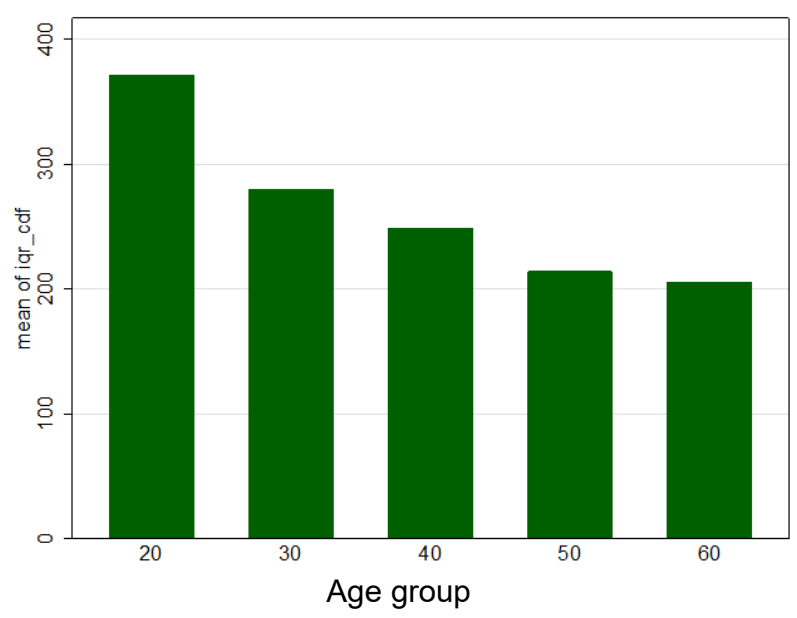

Source: UAS

\subsection{Determinants of subjective expectations}

To find the variables associated with these expectations, we use ordinary least squares to regress the mean of expectations about future retirement benefits on a set of demographic, socioeconomic, and knowledge-related explanatory variables. We restrict the sample to nonretirees ages 30 to 70 . The results are presented in Table 5. Column (1) includes basic demographic and socioeconomic characteristics, including earnings (the inverse hyperbolic sine transformation ${ }^{7}$ ). Column (2) looks at the effect of financial literacy. To differentiate between uncertainty or lack of knowledge and bias in expectations, Column (3) includes categories of self-reported knowledge about future retirement benefits.

${ }^{7}$ For earnings and assets, we use the inverse hyperbolic sine transformation (ins) throughout our analysis. This transformation approximates the natural logarithm and allows retaining zerovalued or negative observations. (MacKinnon and Magee 1990) 
We find that the expectations relate strongly and positively to income, as expected. The level of expected benefits is also positively correlated with education, age, and being male. A higher degree of financial literacy is associated with higher expectations about future benefits. Individuals who declare not knowing what their benefits will be report a significantly lower level of expected benefits.

Table 5: Determinants of expectations about Social Security benefits

\begin{tabular}{|c|c|c|c|}
\hline & \multicolumn{3}{|c|}{ Expected Social Security Benefits } \\
\hline & $\begin{array}{c}\text { Baseline } \\
\text { (1) }\end{array}$ & $\begin{array}{l}\text { Including fin. lit. } \\
\text { (2) }\end{array}$ & 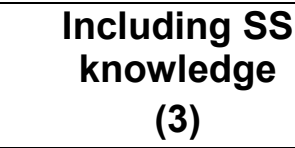 \\
\hline Age expected to claim benef. & $\begin{array}{l}-2.47 \\
(2.05)\end{array}$ & $\begin{array}{l}-2.46 \\
(2.04)\end{array}$ & $\begin{array}{l}-2.61 \\
(2.38)\end{array}$ \\
\hline High school, GED, AD & $\begin{array}{l}156.81 \\
(95.47)\end{array}$ & $\begin{array}{l}137.43 \\
(95.72)\end{array}$ & $\begin{array}{l}18.09 \\
(114.84)\end{array}$ \\
\hline College & $\begin{array}{l}522.58^{* * *} \\
(96.43)\end{array}$ & $\begin{array}{l}482.12^{\star * *} \\
(97.82)\end{array}$ & $\begin{array}{l}308.75^{\star * *} \\
(118.17)\end{array}$ \\
\hline Male & $\begin{array}{l}285.58^{* \star *} \\
(31.54)\end{array}$ & $\begin{array}{l}277.75^{\star \star *} \\
(31.68)\end{array}$ & $\begin{array}{l}253.37^{* * *} \\
(38.99)\end{array}$ \\
\hline Age & $\begin{array}{l}11.68^{* * *} \\
(1.63)\end{array}$ & $\begin{array}{l}11.39^{* * *} \\
(1.63)\end{array}$ & $\begin{array}{l}6.65^{\star \star \star} \\
(2.16)\end{array}$ \\
\hline Earnings (ihs) & $\begin{array}{l}35.10^{\star \star *} \\
(3.89)\end{array}$ & $\begin{array}{l}34.19^{* \star *} \\
(3.90)\end{array}$ & $\begin{array}{l}26.23^{* * *} \\
(4.70)\end{array}$ \\
\hline Financial literacy & & $\begin{array}{l}30.94^{\star *} \\
(13.01)\end{array}$ & $\begin{array}{l}22.38 \\
(16.84)\end{array}$ \\
\hline Have a guess about benefits & & & $\begin{array}{l}-52.54 \\
(81.98)\end{array}$ \\
\hline Have no idea about benefits & & & $\begin{array}{l}-342.73^{\star \star \star} \\
(84.69)\end{array}$ \\
\hline Constant & $\begin{array}{l}324.03^{*} \\
(184.23)\end{array}$ & $\begin{array}{l}259.52 \\
(186.03)\end{array}$ & $\begin{array}{l}918.35^{* * *} \\
(250.74)\end{array}$ \\
\hline Observations & 2,198 & 2,198 & 1,378 \\
\hline R-squared & 0.17 & 0.17 & 0.18 \\
\hline
\end{tabular}

Note: Standard errors in parentheses. ${ }^{* * *} p<0.01,{ }^{* *} p<0.05,{ }^{*} p<0.1$. The omitted category for knowledge about retirement benefits is "I know for certain how much they will be." Source: UAS, nonretirees subsample, ages 30 to 70 
We next consider the variables associated with different levels of uncertainty about future Social Security benefits. To account for the relative importance of the dispersion in expectations with respect to the size of the benefits, we divide the IQR by the mean of the subjective distribution of benefits and consider this as a measure of uncertainty faced by the survey respondents. Table 6 presents the results from regressing this measure of uncertainty on demographic, socioeconomic, and knowledge-related variables.

As in Table 5, the baseline specification in Column (1) includes basic demographic and socioeconomic characteristics, Column (2) looks at the effect of financial literacy, and, Column (3) includes knowledge about future retirement benefits.

In this case, there are not many variables significantly associated with the level of uncertainty. Higher earners and older workers report lower levels of uncertainty. Interestingly, uncertainty is not related to the age at which a respondent is expected to claim benefits. As expected, people who declare not knowing what their benefits will be show significantly higher levels of dispersion in their expectations about future benefits. 
Table 6: Regression results for uncertainty about future retirement benefits

\begin{tabular}{|c|c|c|c|}
\hline & \multicolumn{3}{|c|}{ Uncertainty } \\
\hline & $\begin{array}{c}\text { Baseline } \\
\text { (1) }\end{array}$ & $\begin{array}{c}\text { Including } \\
\text { fin. lit. } \\
\text { (2) }\end{array}$ & $\begin{array}{c}\text { Including } \\
\text { SS } \\
\text { knowledge } \\
\text { (3) }\end{array}$ \\
\hline $\begin{array}{l}\text { Age expected to claim } \\
\text { benef. }\end{array}$ & $\begin{array}{l}-0.042 \\
(0.043)\end{array}$ & $\begin{array}{l}-0.042 \\
(0.043)\end{array}$ & $\begin{array}{l}-0.027 \\
(0.053)\end{array}$ \\
\hline High school, GED, AD & $\begin{array}{l}-3.287 \\
(2.026)\end{array}$ & $\begin{array}{l}-3.329 \\
(2.034)\end{array}$ & $\begin{array}{l}-4.025 \\
(2.552)\end{array}$ \\
\hline College & $\begin{array}{l}-2.677 \\
(2.047)\end{array}$ & $\begin{array}{l}-2.765 \\
(2.079)\end{array}$ & $\begin{array}{l}-3.856 \\
(2.626)\end{array}$ \\
\hline Male & $\begin{array}{l}-0.257 \\
(0.669)\end{array}$ & $\begin{array}{l}-0.274 \\
(0.673)\end{array}$ & $\begin{array}{l}0.016 \\
(0.866)\end{array}$ \\
\hline Age & $\begin{array}{l}-0.317^{\star * *} \\
(0.035)\end{array}$ & $\begin{array}{l}-0.317^{* * *} \\
(0.035)\end{array}$ & $\begin{array}{l}-0.200^{* * *} \\
(0.048)\end{array}$ \\
\hline Earnings (ihs) & $\begin{array}{l}-0.673^{* * *} \\
(0.082)\end{array}$ & $\begin{array}{l}-0.675^{\star * *} \\
(0.083)\end{array}$ & $\begin{array}{l}-0.547^{* * *} \\
(0.105)\end{array}$ \\
\hline Financial literacy & & $\begin{array}{l}0.067 \\
(0.276)\end{array}$ & $\begin{array}{l}0.239 \\
(0.374)\end{array}$ \\
\hline $\begin{array}{l}\text { Have a guess about } \\
\text { benefits }\end{array}$ & & & $\begin{array}{l}2.778 \\
(1.822)\end{array}$ \\
\hline $\begin{array}{l}\text { Have no idea about } \\
\text { benefits }\end{array}$ & & & $\begin{array}{l}8.090^{\star * *} \\
(1.882)\end{array}$ \\
\hline Constant & $\begin{array}{l}43.124^{\star * *} \\
(3.910)\end{array}$ & $\begin{array}{l}42.984^{* * *} \\
(3.953)\end{array}$ & $\begin{array}{l}30.431^{* * *} \\
(5.572)\end{array}$ \\
\hline Observations & 2,198 & 2,198 & 1,378 \\
\hline R-squared & 0.073 & 0.073 & 0.089 \\
\hline
\end{tabular}

Note: Standard errors in parentheses. ${ }^{* * *} p<0.01,{ }^{* *} p<0.05,{ }^{*} p<0.1$. Uncertainty is defined here as $I Q R / E$ (benefits) ${ }^{*} 100$. We scale it as percentage points to facilitate the interpretation of effect sizes. Source: UAS, nonretirees subsample, ages 30 to 70

Figure 10 shows how this uncertainty varies by age group and according to knowledge about future benefits. Uncertainty decreases with age and correlates with 
the respondents' own assessment of their knowledge about their future Social Security benefits.

Figure 10: Uncertainty as function of age and knowledge about Social Security benefits
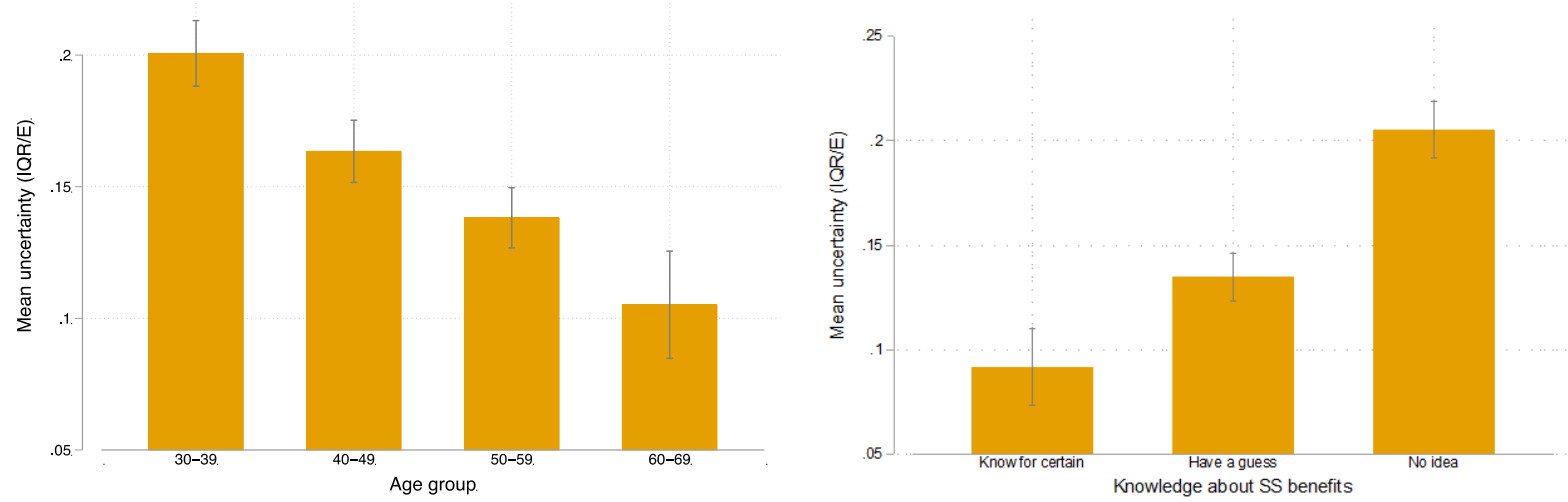

Note: Uncertainty = IQR/E(benefits). Source: UAS, nonretiree subsample

\subsection{Bias in Social Security benefits expectations}

We compute expectation bias about future Social Security benefits. For this, we compare the respondents' expected levels of benefits to our own forecasts. To forecast their future benefits, we apply Social Security Administration's algorithm to the earnings histories elicited from the respondents. We define:

$$
\text { Expectation bias }=E_{\text {Subjective }}(Y)-Y^{\text {forecast }} \text {. }
$$

The Social Security Administration computes retirement benefits, $Y_{S S}$, as a function of the individual i's entire labor earnings ( $z$ ) trajectory, since he or she started 
working at age $j_{1}$ until he or she claims retirement benefits at age $R{ }^{8}$ the individual's birth cohort ( year $\left._{\text {birth }}\right)$ and age of benefit claiming:

$$
Y_{S S}=f_{S S A}\left(\left\{z_{j}^{i}\right\}_{j_{1}}^{R}, R, \text { year }_{\text {birth }}\right) .
$$

In order to forecast the future Social Security retirement benefits of the respondents in our sample, we construct their earnings trajectories using the information provided in the survey to obtain:

$$
Y^{\text {forecast }}=f_{\text {SSA }}(\underbrace{\left\{z_{j}^{i}\right\}_{j_{1}}^{j *}}_{\begin{array}{c}
\text { earnings history } \\
\text { until survey }
\end{array}}, \underbrace{\left\{\hat{z}_{j}^{i}\right\}_{j *}^{R}}_{\begin{array}{c}
\text { earnings forecast } \\
\text { until benefit claiming }
\end{array}}, R, \text { year }_{\text {birth }}) .
$$

\subsubsection{Earnings history}

To construct the earnings history needed for the forecast of retirement benefits, survey respondents were asked about their past labor earnings. For this, we divided the time since the year when they started working to the time of the survey in three periods and asked them about their average labor earnings in each of those three periods. The survey included questions about labor earnings while working and about intervals of nonemployment. Within each period, we transform this step function of past earnings provided by the survey into an age profile of earnings. For this, we use coefficients for the age profile of earnings that vary by gender and education, as estimated from the PSID by Abbott et al. (2018). The details are in Appendix A.1. This generates a sequence of past earnings corresponding to $\left\{z_{j}^{i}\right\}_{j_{1}}^{j *}$.

\footnotetext{
${ }^{8}$ Under certain circumstances, it is possible to grow retirement benefits after claiming for a person who continues working (for example, if the person claimed benefits before full retirement age). Because we only ask about expected benefits at the moment of claiming, we abstract from this possibility in our analysis.
} 


\subsubsection{Forecasts of future earnings}

We use two sources of earnings forecasts for the period after the UAS survey until the expected benefits claiming age. The first source is the subjective distribution of future earnings we elicit from the survey respondents. The means of the each period's distributions provide a step function of expected future earnings. We transform this step function into a yearly sequence of earnings analogously to the transformation used to build the annual earnings history.

The second source is our own forecast for future labor earnings, $\left\{\hat{z}_{j}^{i}\right\}_{j *}^{R}$. We assume real labor earnings for individual $i$ at time $t$ follow this specification:

$$
\log z_{t}^{i}=\alpha+\beta X_{t}^{i}+\log z_{t-1}^{i}+\delta_{t}+\epsilon_{t}^{i},
$$

where the vector of individual characteristics $X_{t}^{i}$ includes gender, an age polynomial of second order, education, marital status, race, and lagged employment. The specification includes time dummies, $\delta_{t} . \epsilon_{t}^{i}$ is assumed to be independent and identically distributed with a normal distribution.

We estimate this specification using an auxiliary sample from the PSID. The sample consists of those 30 and older, nondisabled, nonretired, and in the labor force. We use the PSID survey waves 1990 to 2015 . We then forecast the earnings of the UAS respondents using the estimated coefficients from the auxiliary sample. Appendix A. 2 presents additional details about this process.

When comparing the forecasted earnings using this method to the earnings expected by the respondents, we find that people expect to earn more than what these forecasts indicate. Appendix A.2 presents the distribution of this expectation bias with details by subgroups. 


\subsubsection{Forecast of future Social Security retirement benefits}

For each nonretired respondent in our sample, we forecast future Social Security retirement benefits using information on annual earnings history, age at which the respondent plans to start collecting Social Security benefits, birth year, and forecasts of future earnings. We do this following the rules on benefit determination from the Social Security Administration, as outlined in Appendix A.3.

We use two specifications to forecast retirement benefits. Our preferred specification takes as input the future earnings forecasted from the PSID, we denote it as $Y^{f o r e c}{ }_{P S I D}$. The alternative specification takes as input the earnings predicted by the survey respondents, and we denote it as $Y_{\text {subj. }}^{\text {forec }}$.

\subsubsection{Expectation bias in retirement benefits}

We measure expectation bias as the difference between the forecasted future benefits and the subjective mean of the expected benefits. Table 7 shows the average values for expectation bias (computed using $Y^{f o r e c}{ }_{P S I D}$ ) for population subgroups in our sample. We note that the bias is positive for all groups: On average, each group appears more optimistic about future benefits than implied by the PSID-based forecast. The highest bias corresponds to those with a college degree. The average bias, $\$ 307$, equals $27 \%$ of the average forecasted benefit for this sample.

Potential sources of expectations bias in retirement benefits may be biased expectations about future earnings or lack of knowledge about Social Security benefits rules. One important rule corresponds to benefit adjustments according to whether the individual claims early or delays claiming. We look at how biased expectations about future earnings and lack of adjustment for claiming age may affect expectation biases. 
Table 7: Expectation bias about retirement benefits by subpopulation

\begin{tabular}{|c|c|c|}
\hline & $\begin{array}{l}\text { Expectation bias } \\
\left(=E_{\text {subj }}(Y)-Y_{P S{ }^{f o r e c}}\right)\end{array}$ & $\begin{array}{l}95 \% \text { Confidence } \\
\text { interval }\end{array}$ \\
\hline Sample average & 307.0 & {$[270.5,343.5]$} \\
\hline Female & 326.3 & {$[279.9,372.8]$} \\
\hline Male & 282.1 & {$[223.9,340.4]$} \\
\hline $\begin{array}{l}\text { Less than high } \\
\text { school }\end{array}$ & 79.6 & {$[-63.1,222.4]$} \\
\hline High school & 262.8 & {$[220.3,305.4]$} \\
\hline College & 371.4 & {$[308.0,434.7]$} \\
\hline Not married & 325.3 & {$[263.5,387.0]$} \\
\hline Married & 297.9 & {$[252.7,343.1]$} \\
\hline
\end{tabular}

Note: Bias is defined as the difference between expected monthly Social Security retirement benefits and benefits forecasted using SSA formulas and earnings forecasts computed from PSID estimation.

Figure 11 shows the histograms of benefit expectations bias by gender. It compares the distribution of bias using PSID-forecasted earnings versus using the subjective expectation of future labor earnings. The bias using PSID-forecasted earnings indicates that both genders have a tendency to overestimate their future retirement benefits. Using the future labor earnings expected by the survey respondents would make the bias seem smaller for both genders, as the distributions shift to the left. Both genders are too optimistic about their future earnings, and this is reflected in their expectations about retirement benefits. 
Figure 11: Retirement benefits expectation bias, by gender and source of earnings forecast

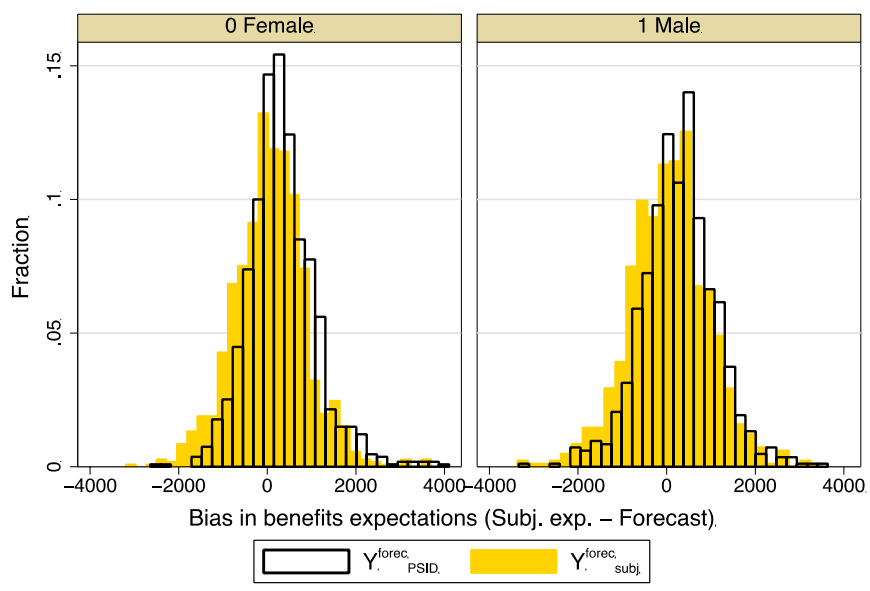

Note: $Y_{P S I D}^{f o r e c}$ takes as input the future earnings forecasted from the PSID. $Y_{\text {subj }}^{\text {forec }}$ uses the respondents' expected future earnings as input.

Figure 12 presents histograms of benefit expectations bias by educational attainment. We explore the role of knowledge about the consequences of early and delayed claiming as potential factors behind benefits expectations. The figure compares the distribution of retirement benefits expectation bias (claim-age adjusted, using the self-reported expected claiming age) versus a version of bias where the benefit forecast is the value at full-retirement age, without accounting for early or delayed claiming (not claim-age adjusted).

Not appropriately adjusting for early or delayed claiming in general reduces the dispersion in biases. In particular, it affects those with lower educational levels the most. For those with less than a high school degree, not appropriately adjusting for early or delayed claiming leads to higher levels of expected benefits, shifting the unadjusted bias distribution to the left. For high school graduates, adjusting for the timing of benefit claiming is less consequential than for the less educated, but it still decreases the 
expected benefits and increases the dispersion in bias. The distribution of bias for college degree holders is less affected by this adjustment.

Figure 12: Retirement benefits expectation bias, by educational attainment

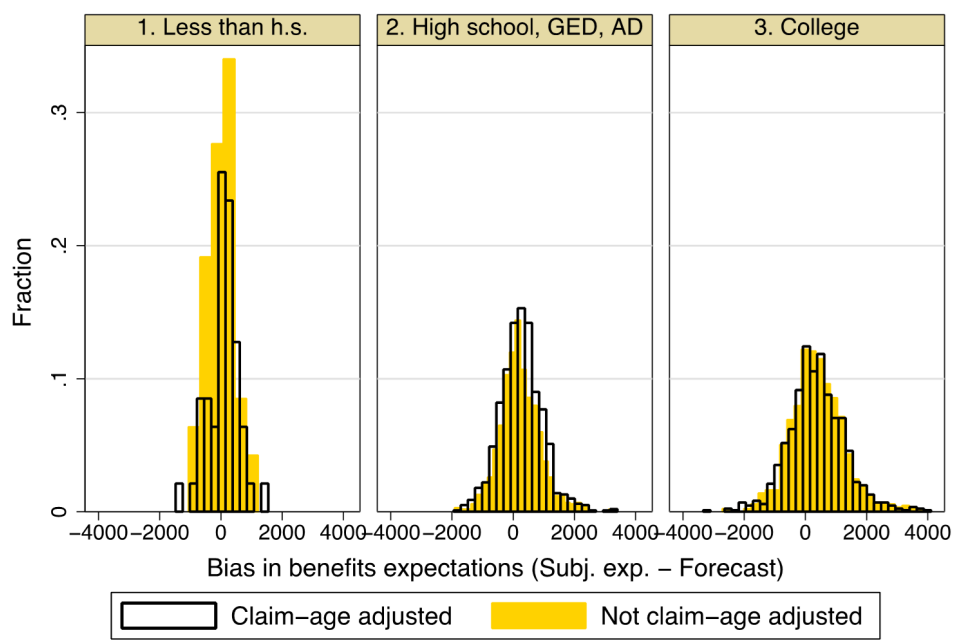

Note: Claim-age adjusted corresponds to the bias computed using benefits forecast $Y^{\text {forec }}{ }_{\text {PSID. }}$ Not claim-age adjusted is the bias computed using benefits forecast not adjusted for early or delayed claiming.

To get a sense of what variables are associated with biased expectations, we regress the expectation bias $\left(E_{\text {sub }}[Y]-Y^{f o r e c}{ }_{P S I D}\right)$ on explanatory variables. Table 8 presents the results. The basic specification in Column (1) only includes demographics. Column (2) also includes a set of variables based on subjective expectations, which include the age at which the individual expects to start claiming retirement benefits, a measure of dispersion of subjective expectations about future retirement benefits - the IQR of the distribution and the bias in earnings expectations. Columns (3) to (5) gradually add other factors that may affect the precision of retirement benefits expectations: financial literacy, attitudes about planning for retirement (planner, rule of thumb, or unsystematic), knowledge about what future benefits will be, and confidence 
that Social Security programs will exist in the future. Because the question about confidence in future availability of Social Security programs was collected in a previous UAS module than the rest of the variables in this survey, the sample size declines when the regression includes this variable.

The results in Table 8 support the view that retirement benefits expectation bias is a function of expected earnings, expected claiming age, and understanding of Social Security rules. Retirement benefits expectation biases are negatively associated with the expected benefit claiming age, which could indicate that individuals are not adequately accounting for early claiming penalties or for the benefits of delayed claiming. Having more uncertainty about future retirement benefits, as captured by the IQR of the subjective distribution, is positively associated with a higher expectation bias. The bias in expected earnings is positively associated with the bias in expected benefits in most specifications, except in the specification in column (3) where the interaction with financial attitudes renders the coefficient on expected earnings bias insignificant.

Most specifications indicate that men have lower expectation bias than women and that age is positively associated with retirement benefits expectation bias. The role of educational attainment is not clear, as those with college have higher biases, but once we control for other factors, the size of the coefficient of the college dummy decreases and becomes insignificant. Financial literacy is weakly associated with higher expectation bias. Those who "have no idea what [their] benefits will be" show much lower expectation bias, perhaps reflecting that they are pessimistic about their future benefits. 
Table 8: Regression models for expectation bias of Social Security benefits

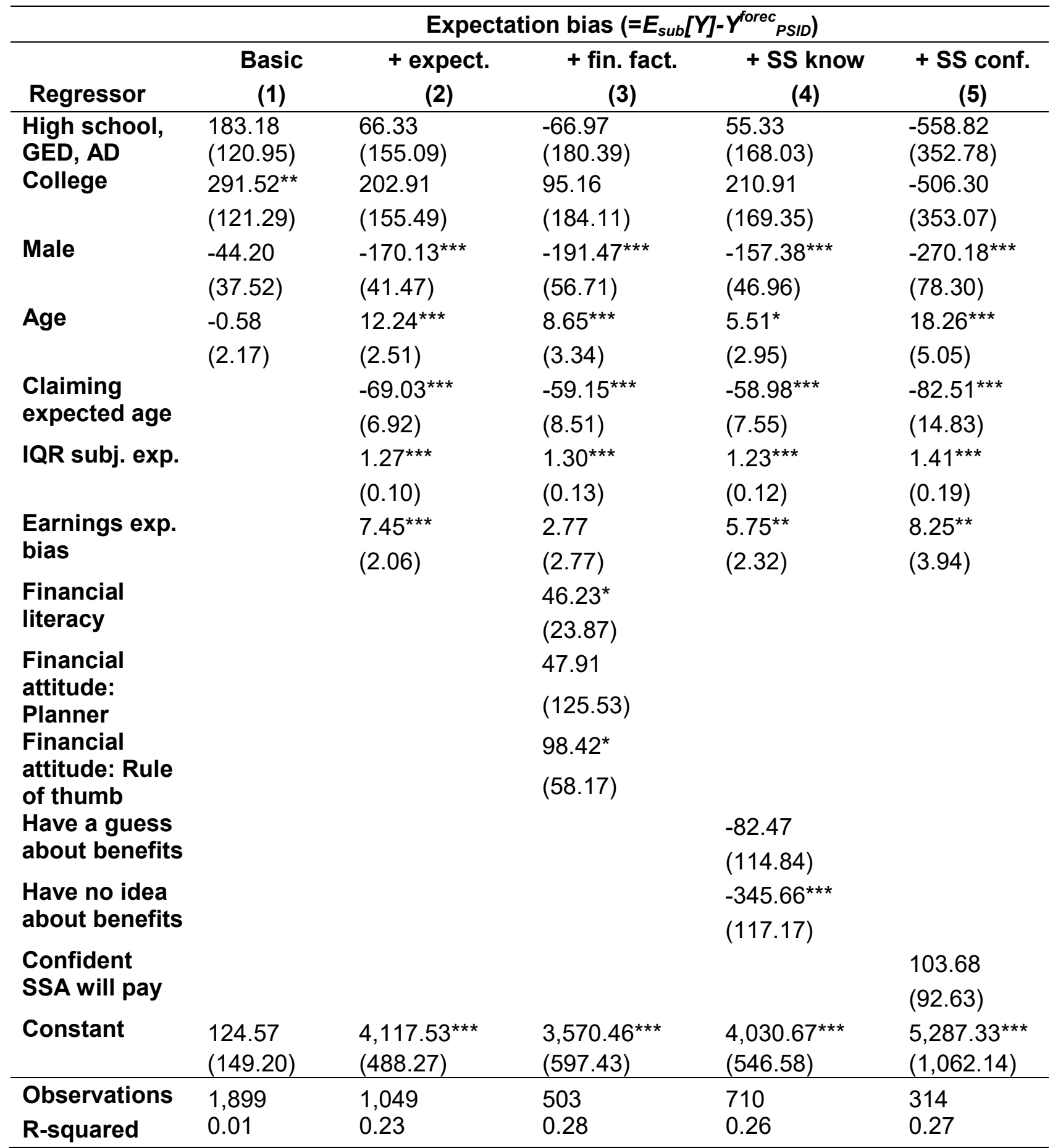

Note: Standard errors in parentheses. ${ }^{* * *} p<0.01,{ }^{* *} p<0.05,{ }^{*} p<0.1$. The omitted category for attitudes with regards to planning for retirement is "unsystematic." The omitted category for knowledge about future Social Security benefits is "I know for certain how much they will be." 
We conduct an alternative analysis focusing on the sign of the expectation bias. For this, we define an indicator for whether individuals overestimate or underestimate the amount of retirement benefits they will receive from Social Security. On average, individuals in our sample tend to overestimate the level of retirement benefits they will receive from Social Security. We fit a probit model to predict the likelihood of overestimating future benefits. Table 9 presents the estimated marginal effects from these regressions. The specification in Column (1) includes demographics and years to benefit claiming. Column (2) also includes the dispersion of subjective expectations about future retirement benefits measured by the IQR. Column (3) adds labor earnings. Columns (4) and (5) include other factors that may affect the expectations about retirement benefits: financial literacy, attitudes about planning for retirement (planner, rule of thumb, or unsystematic), and knowledge about what future benefits will be.

The results show that individuals closer to their intended benefit claiming age and older individuals are less likely to overestimate their future benefits. As in the regressions for the level of expectation bias, educational attainment does not appear to have a significant effect on the probability of overestimation. Having a college degree is not associated with a higher probability of overestimating benefits. Individuals with higher earnings are more likely to overestimate their future retirement benefits from Social Security. ${ }^{9}$ Men are less likely than women to overestimate their benefits, but the effect becomes insignificant once we control for financial literacy and attitudes.

\footnotetext{
${ }^{9}$ Unlike in the case of gender, earnings remain significant after controlling for financial literacy and planning attitudes in additional regression results (not reported in Table 9).
} 
Table 9: Average marginal effect estimates of the probability of overestimating future Social Security retirement benefits

\begin{tabular}{|c|c|c|c|c|c|}
\hline \multirow[b]{2}{*}{ Regressor } & \multicolumn{5}{|c|}{$\begin{array}{l}\text { Probability of overestimating future benefits - } \\
\left.\operatorname{Pr}\left(E_{\text {subir }} Y\right]>Y^{\text {forec }} P S \mid D\right)\end{array}$} \\
\hline & $\begin{array}{c}\text { Basic } \\
\text { (1) }\end{array}$ & $\begin{array}{l}\text { Incl. } \\
\text { uncert. } \\
\text { (2) }\end{array}$ & $\begin{array}{l}\text { Incl. } \\
\text { earn. } \\
\text { (3) }\end{array}$ & $\begin{array}{l}\text { Incl. fin. } \\
\text { attitudes } \\
\text { (4) }\end{array}$ & $\begin{array}{c}\text { Incl. SS } \\
\text { knowl. } \\
(5)\end{array}$ \\
\hline Years to benefits & $\begin{array}{l}-0.04^{* * *} \\
(0.00)\end{array}$ & $\begin{array}{l}-0.04^{\star \star \star} \\
(0.00)\end{array}$ & $\begin{array}{l}-0.04^{* * *} \\
(0.00)\end{array}$ & $\begin{array}{l}-0.04^{* \star *} \\
(0.00)\end{array}$ & $\begin{array}{l}-0.04^{\star \star \star} \\
(0.00)\end{array}$ \\
\hline High school, GED, AD & $\begin{array}{l}0.05 \\
(0.07)\end{array}$ & $\begin{array}{l}0.03 \\
(0.06)\end{array}$ & $\begin{array}{l}-0.00 \\
(0.06)\end{array}$ & $\begin{array}{l}0.03 \\
(0.08)\end{array}$ & $\begin{array}{l}0.01 \\
(0.08)\end{array}$ \\
\hline College & $\begin{array}{l}0.09 \\
(0.07)\end{array}$ & $\begin{array}{l}0.05 \\
(0.06)\end{array}$ & $\begin{array}{l}0.00 \\
(0.06)\end{array}$ & $\begin{array}{l}0.05 \\
(0.08)\end{array}$ & $\begin{array}{l}0.02 \\
(0.08)\end{array}$ \\
\hline Male & $\begin{array}{l}-0.03 \\
(0.02)\end{array}$ & $\begin{array}{l}-0.05^{* *} \\
(0.02)\end{array}$ & $\begin{array}{l}-0.06^{* * *} \\
(0.02)\end{array}$ & $\begin{array}{l}-0.03 \\
(0.03)\end{array}$ & $\begin{array}{l}-0.03 \\
(0.03)\end{array}$ \\
\hline Age & $\begin{array}{l}-0.08^{* * *} \\
(0.01)\end{array}$ & $\begin{array}{l}-0.08^{* * *} \\
(0.01)\end{array}$ & $\begin{array}{l}-0.08^{* * *} \\
(0.01)\end{array}$ & $\begin{array}{l}-0.05^{\star * *} \\
(0.02)\end{array}$ & $\begin{array}{l}-0.05^{* * *} \\
(0.02)\end{array}$ \\
\hline $\mathrm{Age}^{2}$ & $\begin{array}{l}0.00^{* * *} \\
(0.00)\end{array}$ & $\begin{array}{l}0.00^{* * *} \\
(0.00)\end{array}$ & $\begin{array}{l}0.00^{* * *} \\
(0.00)\end{array}$ & $\begin{array}{l}0.00 \\
(0.00)\end{array}$ & $\begin{array}{l}0.00 \\
(0.00)\end{array}$ \\
\hline IQR subj.expec. & & $\begin{array}{l}0.06^{* * *} \\
(0.01)\end{array}$ & $\begin{array}{l}0.06^{* * *} \\
(0.01)\end{array}$ & $\begin{array}{l}0.06^{* * *} \\
(0.01)\end{array}$ & $\begin{array}{l}0.06^{* * *} \\
(0.01)\end{array}$ \\
\hline Earnings (ihs) & & & $\begin{array}{l}0.01^{* * *} \\
(0.00)\end{array}$ & & \\
\hline Financial literacy & & & & $\begin{array}{l}0.00 \\
(0.01)\end{array}$ & $\begin{array}{l}-0.00 \\
(0.01)\end{array}$ \\
\hline Planner & & & & $\begin{array}{l}0.05 \\
(0.05)\end{array}$ & $\begin{array}{l}0.03 \\
(0.05)\end{array}$ \\
\hline Rule of thumb & & & & $\begin{array}{l}0.05 \\
(0.03)\end{array}$ & $\begin{array}{l}0.01 \\
(0.03)\end{array}$ \\
\hline $\begin{array}{l}\text { Have a guess about } \\
\text { benefits }\end{array}$ & & & & & -0.07 \\
\hline & & & & & $(0.08)$ \\
\hline $\begin{array}{l}\text { Have no idea about } \\
\text { benefits }\end{array}$ & & & & & $-0.22^{\star * *}$ \\
\hline & & & & & $(0.08)$ \\
\hline Observations & 1,899 & 1,899 & 1,892 & 1,048 & 1,048 \\
\hline Pseudo R2 & 0.063 & 0.098 & 0.110 & 0.091 & 0.113 \\
\hline
\end{tabular}

Note: The units of the IQR in this regression are hundreds of dollars. The omitted category for attitudes with regards to planning for retirement is "unsystematic." The omitted category for knowledge about future Social Security benefits is "I know for certain how much they will be"; (ihs) indicates inverse hyperbolic sine transformation. 
Similarly to the regressions for the level of expectation bias, a higher dispersion in benefit expectations is associated with an increased probability of overestimating future benefits. Financial literacy and attitudes toward financial planning are not significant. Interestingly, those who claim to have no knowledge of their future benefits are more likely to err on the conservative side and underestimate their future benefits.

\subsection{Patterns of asset accumulation}

We look at the main factors correlated with the total net wealth amount accumulated by the nonretired individuals in our sample. The literature has devoted much attention to measuring and describing the relationship between financial literacy, numeracy, and financial decisions (e.g. Banks et al. 2010; Ameriks et al. 2003; Lusardi and Mitchell 2007; Lusardi et al. 2017). Therefore, we incorporate these aspects in our analysis. We estimate the following regression:

$$
\text { Wealth }=\beta_{0} * X+\beta_{1} * \text { Earnings }+\beta_{2} * \overrightarrow{E x p}+\beta_{3} * \text { Uncertainty }+\beta_{4} * \text { FinLit }+
$$

$\beta_{5} *$ Plan $+\epsilon$,

where $X$ is a vector of demographic characteristics (gender, age, race/ethnicity, marital status, educational attainment); $\overrightarrow{E x p}$ is a vector that includes expected retirement age, expectations about future Social Security retirement benefits, and future earnings expectations; Plan is the attitude about planning type (planner, rule of thumb, unsystematic); and FinLit is the financial literacy score.

Table 10 shows the regression estimates. All specifications include demographic characteristics. The models in Columns (1) to (3) include different subsets of expectations and uncertainty. Column (4) includes the bias in retirement benefits expectations. 


\section{Table 10: Regression models of total net wealth}

\begin{tabular}{|c|c|c|c|c|}
\hline Regressor & $\begin{array}{c}\text { Baseline } \\
(1)\end{array}$ & $\begin{array}{c}\text { Incl. } \\
\text { uncert. } \\
\text { (2) }\end{array}$ & $\begin{array}{c}\text { Incl. fin. } \\
\text { attitude } \\
(3)\end{array}$ & $\begin{array}{c}\text { Incl. exp. } \\
\text { bias } \\
(4)\end{array}$ \\
\hline Income, hh (ihs) & $\begin{array}{l}0.07 \\
(0.08)\end{array}$ & $\begin{array}{l}0.11 \\
(0.08)\end{array}$ & $\begin{array}{l}0.08 \\
(0.09)\end{array}$ & $\begin{array}{l}0.07 \\
(0.09)\end{array}$ \\
\hline $\begin{array}{l}\text { Years to exp. } \\
\text { retirement }\end{array}$ & $\begin{array}{l}-0.03^{* *} \\
(0.01)\end{array}$ & $\begin{array}{l}-0.04^{* * *} \\
(0.01)\end{array}$ & $\begin{array}{l}-0.03^{* *} \\
(0.01)\end{array}$ & $\begin{array}{l}-0.04^{* *} \\
(0.01)\end{array}$ \\
\hline $\begin{array}{l}\text { Exp. avg. future } \\
\text { earnings }\end{array}$ & $\begin{array}{l}0.37 \\
(0.28)\end{array}$ & $\begin{array}{l}0.57^{* *} \\
(0.27)\end{array}$ & $\begin{array}{l}0.23 \\
(0.32)\end{array}$ & $\begin{array}{l}0.47 \\
(0.33)\end{array}$ \\
\hline $\begin{array}{l}\text { Expected SS ret } \\
\text { ben (log) }\end{array}$ & $\begin{array}{l}1.27^{* * *} \\
(0.40)\end{array}$ & & $\begin{array}{l}1.09^{* *} \\
(0.48)\end{array}$ & \\
\hline $\begin{array}{l}\text { IQR SS benef. } \\
\text { (log) }\end{array}$ & & $\begin{array}{l}0.55^{* *} \\
(0.23)\end{array}$ & $\begin{array}{l}0.38 \\
(0.27)\end{array}$ & \\
\hline Financial literacy & & & $\begin{array}{l}0.42^{* *} \\
(0.20)\end{array}$ & $\begin{array}{l}0.46^{* *} \\
(0.21)\end{array}$ \\
\hline Rule of thumb & & & $\begin{array}{l}-0.99 \\
(0.69)\end{array}$ & $\begin{array}{l}-1.03 \\
(0.76)\end{array}$ \\
\hline Unsystematic & & & $\begin{array}{l}-2.20^{* * *} \\
(0.73)\end{array}$ & $\begin{array}{l}-2.28^{* * *} \\
(0.79)\end{array}$ \\
\hline $\begin{array}{l}\text { Ret. benef. } \\
\text { expectat. bias }\end{array}$ & & & & $\begin{array}{l}0.00 \\
(0.00)\end{array}$ \\
\hline Constant & $\begin{array}{l}-16.33^{* * *} \\
(6.22)\end{array}$ & $\begin{array}{l}-11.21^{*} \\
(6.05)\end{array}$ & $\begin{array}{l}-11.03 \\
(7.04)\end{array}$ & $\begin{array}{l}-3.66 \\
(8.00)\end{array}$ \\
\hline Other controls & $\mathrm{Y}$ & $\mathrm{Y}$ & $\mathrm{Y}$ & $\mathrm{Y}$ \\
\hline Observations & 1,241 & 1,205 & 991 & 932 \\
\hline R-squared & 0.14 & 0.13 & 0.16 & 0.14 \\
\hline
\end{tabular}

Note: Standard errors in parentheses. ${ }^{* *} p<0.01,{ }^{* *} p<0.05,{ }^{*} p<0.1$. Other controls include a second-degree polynomial in age and indicators of race/ethnicity, gender, educational attainment, and marital status. (ihs) indicates inverse hyperbolic sine transformation; (log) indicates natural logarithm transformation.

The estimates in Table 10 indicate that total net worth is higher for those closer to retirement, as predicted by the life-cycle model. Uncertainty about retirement benefits, measured as IQR of benefits expectations, is positively associated with net 
worth accumulation, but the effect disappears when we control for financial literacy and propensity to plan. The expectation about future benefits is positively associated with asset levels. However, this does not hold for the case of net financial assets. ${ }^{10}$ This may indicate that optimism about future benefits translates to investments in illiquid assets such as housing, while it does not affect financial wealth. Biased retirement benefits expectations are not associated with wealth levels.

\section{Model and numerical results}

To identify the effects of subjective expectations on household behavior and asset accumulation, we use a life-cycle model of savings. We assume the following household optimization problem: Every period, households choose how much to consume and save to maximize the present discounted value of expected lifetime utility, subject to risky labor earnings. When they retire, they receive retirement benefits, which are a function of their realized labor earnings. Households hold expectations regarding future labor earnings, retirement age,${ }^{11}$ and retirement benefits.

Households derive utility from consumption and their utility function is time separable. We assume the labor earnings process to be exogenous. Thus individuals do not choose how much to work and all fluctuations in earnings arise from the exogenous earnings process. Taxes (OASDI) are a function of household income, and Social Security retirement benefits are a function of lifetime earnings.

\footnotetext{
${ }^{10}$ We do not report these regression results. They are available upon request.

${ }^{11}$ For the sake of simplicity, we assume retirement and benefit claiming age are the same.
} 
The dynamic optimization problem that a household $i$ solves at age $j$ can be written as follows:

$$
V_{j}^{i}\left(a_{j}^{i}, y_{j}^{i} ; \Theta_{j}^{i}\right)=\max _{c_{j}^{i}, a_{j+1}^{i}}\left\{u\left(c_{j}^{i}\right)+\beta E_{j} V_{j+1}^{i}\left(a_{j}^{i}, y_{j}^{i} ; \Theta_{j+1}^{i}\right)\right\}
$$

subject to:

$$
\begin{gathered}
c_{j}^{i}+m_{j}^{i}+a_{j+1}^{i}=(1+r) a_{j}^{i}+y_{j}^{i}(1-\tau) \\
y=\left\{\begin{array}{cc}
r a_{j}^{i}+z_{j}^{i}, & \text { if } j<R \\
r a_{j}^{i}+S S\left(\sum_{j=j_{0}}^{R} z_{j}^{i}\right), & \text { if } j \geq R
\end{array}\right. \\
z_{j+1}^{i} \sim F\left(z_{j}^{i}, j\right) \\
c_{j}^{i} \geq 0 \\
a_{j+1}^{i} \geq \text { natural borrowing limit. }
\end{gathered}
$$

The Constant Relative Risk Aversion (CRRA) utility function is given by:

$$
u\left(c_{j}^{i}\right)=\frac{c_{j}^{i^{1-\gamma}}-1}{1-\gamma} .
$$

$\Theta^{i}=\{F(),. S S()$.$\} is the information set of household i$, which includes the process for labor earnings and the knowledge of the rules to determine Social Security retirement benefits. $R$ is the retirement age, $c^{i}$ is consumption, $a^{i}$ is assets, $\beta$ is the discount factor, $r$ is the annual interest rate, $z^{i}$ is labor earnings, $\tau($.$) is the income tax$ function, and $S S($.$) are Social Security benefits as function of lifetime earnings. For$ simplicity, the model assumes that the retirement age coincides with the retirement benefits claiming age.

Each household's information set includes their expectations about future labor earnings and retirement benefits. We assume no updating of the information set during 
the lifetime of the household. In the subjective expectations specification, the household information set need not match the actual functional form of Social Security benefits or the statistical process of labor earnings. Instead, we use the subjective expectations data from our survey to approximate the subjective information set.

We use the survey data to estimate the model and compute the optimal savings path under different scenarios, depending on the information set that households use: We assess the importance of subjective expectations for household wealth dynamics and welfare by comparing the savings and welfare predicted by the subjective expectations model to those predicted by the rational expectations model, where the information set includes objectively forecasted future earnings and the formula for Social Security retirement benefits dependent on realized earnings.

\subsection{Calibration}

For the rational expectations specification, we estimate the statistical process for future earnings from our sample's full forecasted earnings. We assume the true labor earnings process is a persistent process, following a simple standard specification, given by:

$$
\begin{gathered}
\log z_{j}^{i}=\alpha_{j}^{i}+\rho \log z_{j-1}^{i}+\epsilon_{j}^{i} \\
\epsilon_{j}^{i} \sim N(0, \sigma),
\end{gathered}
$$

where $\alpha$ is an idiosyncratic fixed effect, $\rho$ is the persistence of the process, and $\epsilon$ is the transitory component, which follows a normal distribution with standard deviation $\sigma$. This specification is a good statistical approximation of the earnings process. 
For the subjective expectations about labor earnings, we estimate a similar statistical process using the future earnings process corresponding to our survey respondents' expectations.

We start the life-cycle simulation at age 30 . We assume individuals retire when they turn 67 - the current full retirement age for individuals born after 1960 - and they live until age 85 with certainty. Appendix A.4 includes additional details of the parameterization of the model.

\subsection{Simulations}

We compare the rational expectations outcomes to those that would occur if the individuals use their subjective expectations about income and retirement benefits. For that, we decompose the subjective information set to analyze the consequences of different aspects of it.

\subsubsection{Subjective expectations about retirement benefits}

We solve the optimization problem of individuals using the expected distribution of future retirement benefits from the UAS survey data. On average, individuals overestimate their future retirement benefits and are uncertain about their amounts, as seen in Section 3.4.4. We simulate 200 paths for the labor earnings process. We then calculate the resulting consumption, assets, and utility levels derived from using the policy functions for consumption and assets under subjective expectations, using as input the simulated earnings and retirement benefits paths from the objective forecasts.

The results for the average consumption and assets paths under this scenario are shown in Figure 13. They are compared with the optimal paths under the rational expectations scenario. Panel (a) shows the average path for consumption. The path 
derived using subjective expectations, results in too much consumption during the working years and too little consumption in retirement, compared to the rational expectations path. Panel (b) shows the average pattern of asset accumulation over the life cycle for these simulations. Individuals accumulate fewer assets while working when they follow their subjective expectations than in the rational expectations scenario. As a result of these discrepancies between the rational expectations paths and the paths under subjective expectations, the present discounted value of lifetime utility in the rational expectations model is $1 \%$ higher than the present discounted value of lifetime utility resulting from the subjective expectations about retirement benefits.

Figure 13: Consumption and asset accumulation paths under rational expectations versus subjective expectations

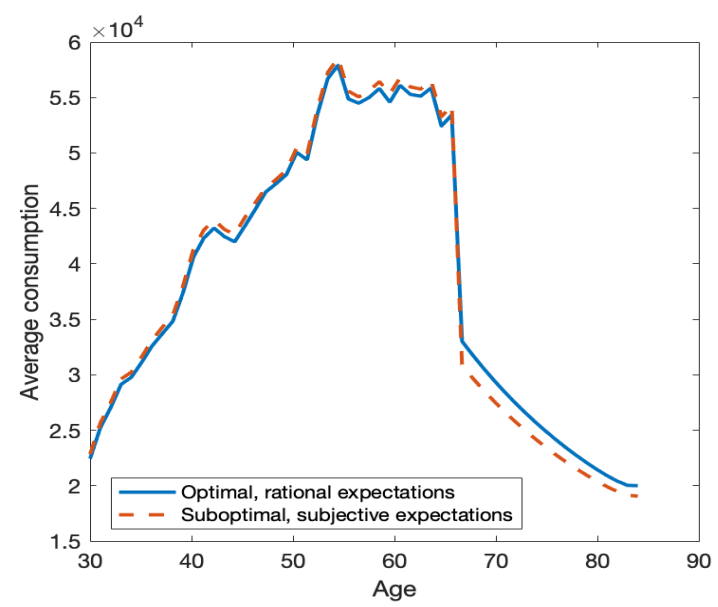

(a) Consumption paths

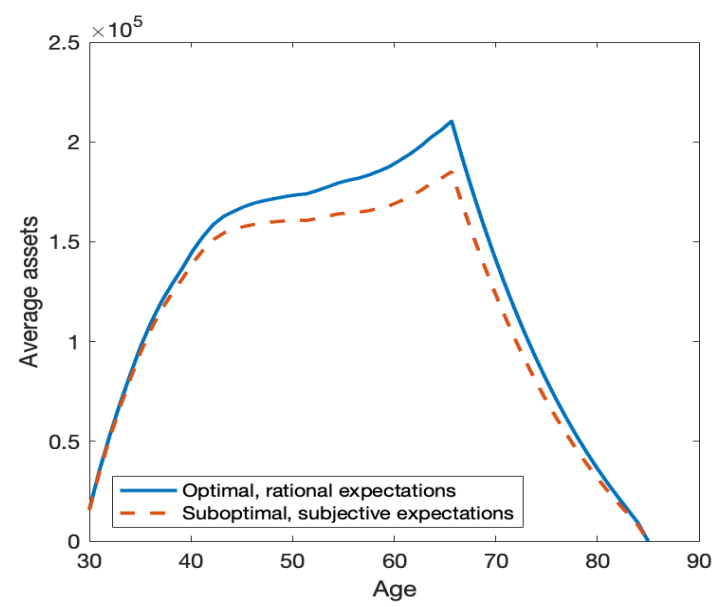

(b) Assets paths

\subsubsection{Decomposition of subjective expectations about retirement benefits}

The subjective expectations about retirement differ with respect to their mean forecast and also the degree of uncertainty. We decompose the effect along these two dimensions. We first look at the effects on the individual optimization problem of 
expecting retirement benefits that are too high for their earnings history. For this, we solve individuals' optimization problems with the average level of retirement benefits expectation bias, taken from the survey data. We assume the labor earnings process corresponds to the rational expectations case and there is no added uncertainty about retirement benefit amounts. The resulting consumption and savings paths are the "bias" results.

Next, we compute the optimal consumption and savings policies derived when there is uncertainty about the future benefit level but the average corresponds to the objective forecast. We solve the individual optimization problem under the scenario of added retirement benefits uncertainty and simulate the outcomes for 200 realizations of the earnings path. The consumption and savings paths are the "uncertainty" results.

The results for the average consumption and assets paths under these scenarios are shown in Figure 14. Panel (a) shows the average paths for consumption, and panel (b) shows the average patterns of asset accumulation over the life cycle for these simulations. The behavior based on biased benefits expectations results in too much consumption during the working years and too little consumption in retirement when compared to the rational expectations outcome. In this case, individuals accumulate fewer assets while working than in the rational expectations scenario because they overestimate the level of benefits they'll receive during retirement. This means a welfare loss of $0.54 \%$. When there is high uncertainty, there is less consumption during the working years and more consumption during retirement. This precautionary savings behavior is reflected in the pattern of assets accumulation. The welfare loss in this case is $0.74 \%$. 
Figure 14: Consumption and asset accumulation paths under rational expectations versus subjective expectations and uncertainty

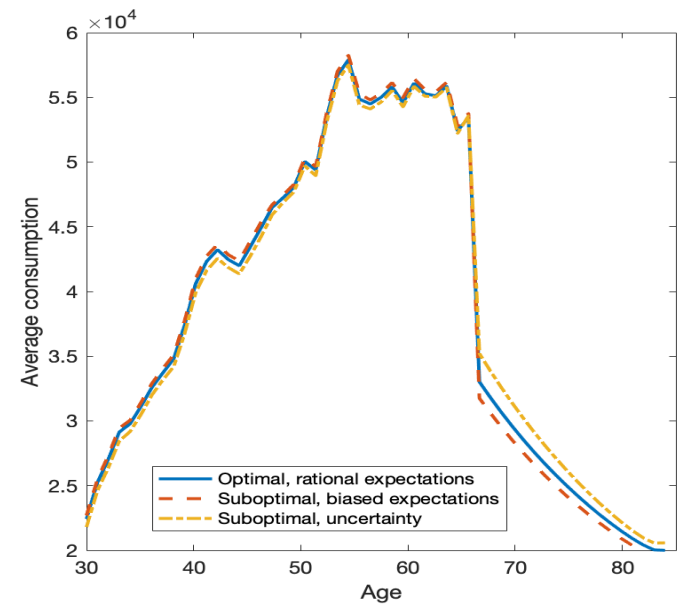

(a) Consumption paths

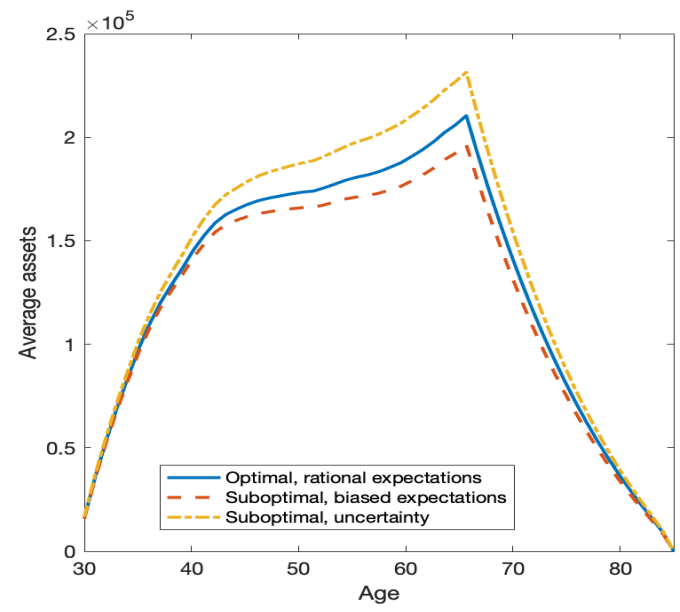

(b) Assets paths

\subsubsection{Subjective expectations about future labor earnings and retirement benefits}

Lastly, we consider the implications of behaving according to the full set of subjective expectations, including expectations about labor earnings as well as about retirement benefits. We perform the same exercise as before: We derive the policies for savings and consumption using the subjective expectations for earnings and benefits distributions. We then simulate earnings paths from the forecasted distribution and use those policies to compute consumption and asset accumulation patterns. The average paths resulting from these simulations are shown in Figure 15. In this case, the discrepancy between the subjective expectations life-cycle patterns and the rational expectations ones results in lower asset accumulation and a welfare loss of $3.5 \%$. 
Figure 15: Consumption and asset accumulation paths under rational expectations versus subjective expectations

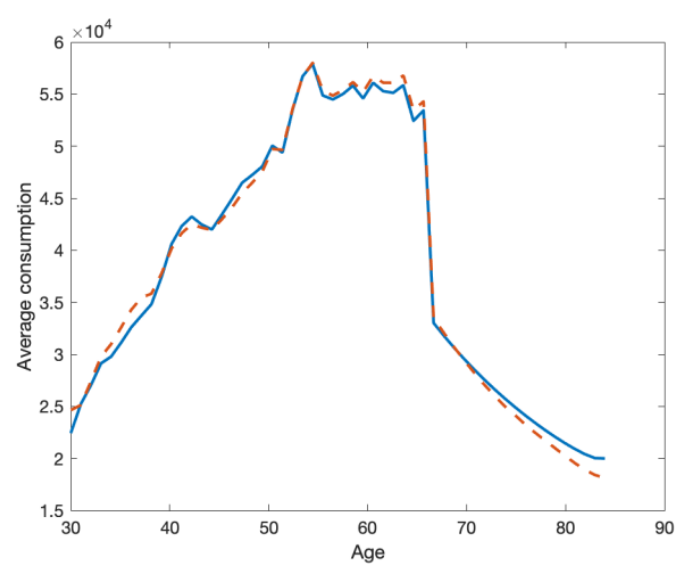

(a) Average consumption paths

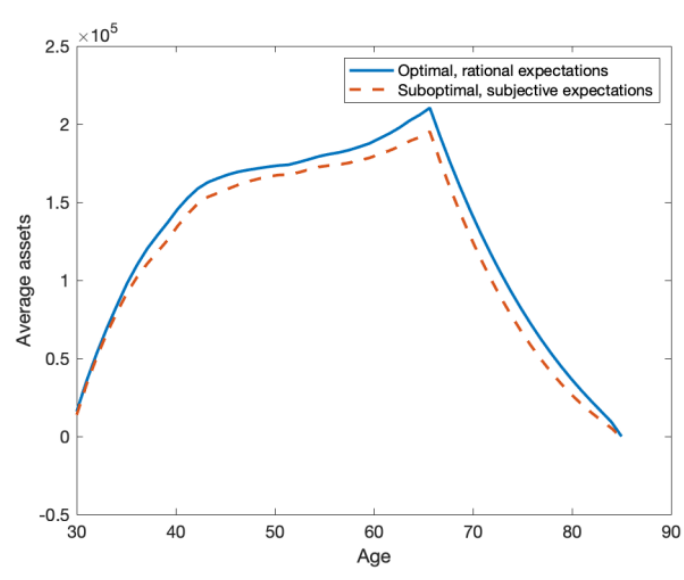

(b) Average assets paths

\section{Conclusions}

Our results indicate that there is sizable uncertainty about future retirement benefits among nonretirees. We estimate that this uncertainty affects wealth accumulation by workers, as a result of precautionary savings. Our results on retirees corroborate that expectations about retirement are often biased, as retired individuals reported that on average they had been too optimistic about their retirement benefits. The relevance of these biased expectations is that they can lead, on average, to lower savings for retirement than would be optimal. Moreover, our results indicate that this affects the experience of retirement.

A large fraction of retirees express regrets about choices they made about retirement. This has important policy implications. If individuals could reduce their uncertainty about future retirement, they would probably have fewer regrets after 
retirement. In survey data from current workers, we find significant biases in retirement benefits expectations. Possible reasons for biased expectations and excess uncertainty about future benefits include overly optimistic predictions of future labor earnings and failure to properly adjust for early or delayed benefit claiming. Failure to properly adjust for early claiming would affect the less educated relatively more.

These biases in retirement benefits expectations are higher among women, those who expect to claim earlier, and those with a high level of uncertainty about their future retirement benefits. As individuals get closer to their claiming age, they are less likely to overestimate their benefits. We find no difference in the probability of overestimating future retirement benefits by educational levels, but there are gender differences, with men being less likely to overestimate their future benefits. The importance of overestimating retirement benefits is that it may affect saving behavior and retirement preparedness.

To measure the extent of these effects, we simulate a life-cycle model calibrated to match our survey data. Our simulation results indicate welfare losses from lack of accurate knowledge about the amounts of Social Security retirement benefits to be expected. This results in inadequate levels of asset accumulation before retirement. We find that this leads to a $1 \%$ loss in welfare when compared to the behavior based on rational expectations, considering earnings uncertainty and the appropriate Social Security rules governing the determination of retirement benefits. 


\section{References}

Abbott, B., Gallipoli, G., Meghir, C., \& Violante, G. L. (2018). Education policy and intergenerational transfers in equilibrium. Journal of Political Economy, forthcoming.

Ameriks, J., Caplin, A., and Leahy, J. (2003). Wealth accumulation and the propensity to plan. The Quarterly Journal of Economics, 118(3), 1007-1047.

Banks, J., o'Dea, C., and Oldfield, Z. (2010). Cognitive function, numeracy and retirement saving trajectories. The Economic Journal, 120(548), F381-F410.

Benítez-Silva, H., B. Demiralp, Z. Liu, et al. (2009). Social security literacy and retirement well-being.

Binswanger, J. and K. G. Carman (2012). How real people make long-term decisions: The case of retirement preparation. Journal of Economic Behavior \& Organization 81(1), 39-60.

Cross National Equivalent File (CNEF). User Package for the Panel Study of Income Dynamics, 1970-2017. Ohio State University.

De Nardi, M., E. French, and J. B. Jones (2010). Why do the elderly save? the role of medical expenses. Journal of Political Economy 118(1), 39-75.

De Nardi, M. and F. Yang (2014). Bequests and heterogeneity in retirement wealth. European Economic Review 72, 182-196.

Delavande, A. and S. Rohwedder (2008). Eliciting subjective probabilities in internet surveys. Public Opinion Quarterly 72(5), 866-891.

Dominitz, J. and C. F. Manski (1997). Using expectations data to study subjective income expectations. Journal of the American statistical Association 92(439), 855-867. 
Dominitz, J. and C. F. Manski (2006). Measuring pension-benefit expectations probabilistically. Labour 20(2), 201-236.

Laitner, J. and F. T. Juster (1996). New evidence on altruism: A study of TIAA-CREF retirees. The American Economic Review, 893-908.

Lockwood, L. M. (2018). Incidental bequests and the choice to self-insure late-life risks. American Economic Review, 108(9), 2513-50.

Lusardi, A., P.-C. Michaud, and O. S. Mitchell (2017). Optimal financial knowledge and wealth inequality. Journal of Political Economy, 125(2), 431-477.

Lusardi, A., \& Mitchell, O. S. (2007). Financial literacy and retirement planning: New evidence from the Rand American Life Panel. Michigan Retirement Research Center Research Paper No. WP, 157.

MacKinnon, J. G., and Magee, L. (1990). Transforming the dependent variable in regression models. International Economic Review, 315-339.

Poterba, J. M. (2014). Retirement security in an aging population. American Economic Review 104(5), 1-30.

Prados, M. J. and Kapteyn, A. (2016). Alternative formats to elicit subjective expectations about future labor income. Technical report.

Scholz, J. K., A. Seshadri, and S. Khitatrakun (2006). Are Americans saving "optimally" for retirement? Journal of Political Economy 114(4).

Social Security Administration. The 2018 Annual Report of the Board of Trustees of the Federal Old-Age and Survivors Insurance and Federal Disability Insurance Trust Funds.

Yoong, J., L. Rabinovich, and H. W. Saw (2015). What do people know about social security? Technical report, Center for Economic and Social Research, University of Southern California. 


\section{Appendix}

\section{A.1 Earnings history}

The UAS asks about past earnings in a succinct way. Depending on how long the respondents have been participating in the labor force, they were asked about their average past earnings over their work history divided in one, two, or three periods. This produces a short sequence of average past earnings over $N$ periods, $\{\hat{Y}\}_{N}{ }^{12}$ Where, $\hat{Y}_{n}$ is the average nominal earnings reported for period $n$, corresponding to $X$ years.

Therefore, if $Y_{t}$ and $y_{t}$ are nominal and real earnings in year $t$, respectively, the relation between these variables is given by:

$$
\begin{aligned}
& \hat{Y}_{n}=\sum_{t=t_{n} \ldots t_{n}+X} \frac{Y_{t}}{X} \\
& =\sum_{t=t_{n} \ldots t_{n}+X} \frac{y_{t} * C P I_{t}}{X}
\end{aligned}
$$

Approximating $y_{t}$ with a quadratic function of age, (a.1) results in:

$$
\begin{aligned}
& \sum_{t=t_{n} \ldots t_{n}+X} \frac{\exp \left\{\beta x_{t}+\alpha_{1} * j+\alpha_{2} * j^{2}\right\} * C P I_{t}}{X} \\
= & \frac{\exp \left\{\beta x_{t}\right\}}{X} \underbrace{\sum_{t=t_{n} \ldots t_{n}+X} \exp \left\{\alpha_{1} * j+\alpha_{2} * j^{2}\right\} * C P I_{t}}_{k_{J X}}
\end{aligned}
$$

where $x$ is a vector of individual characteristics and $j$ is age.

Therefore, the annual values of past earnings are given by:

\footnotetext{
${ }^{12}$ For notational simplicity, we ignore the superscript corresponding to individual $i$.
} 
$Y_{t}=\exp \left\{\beta x_{t}\right\} * \exp \left\{\alpha_{1} * j+\alpha_{2} * j^{2}\right\} * C P I_{t}=X \frac{\hat{Y}_{n}}{k_{J X}} * \exp \left\{\alpha_{1} * j+\alpha_{2} * j^{2}\right\} * C P I_{t}$

We use this formula to fit an age profile to the earnings history data in the survey using the estimates by Abbott et al. (2018). Figure A.1 presents an example of what that results in for a representative respondent.

Figure A.1: Earnings history for a survey respondent, survey raw data versus fitted to an age profile

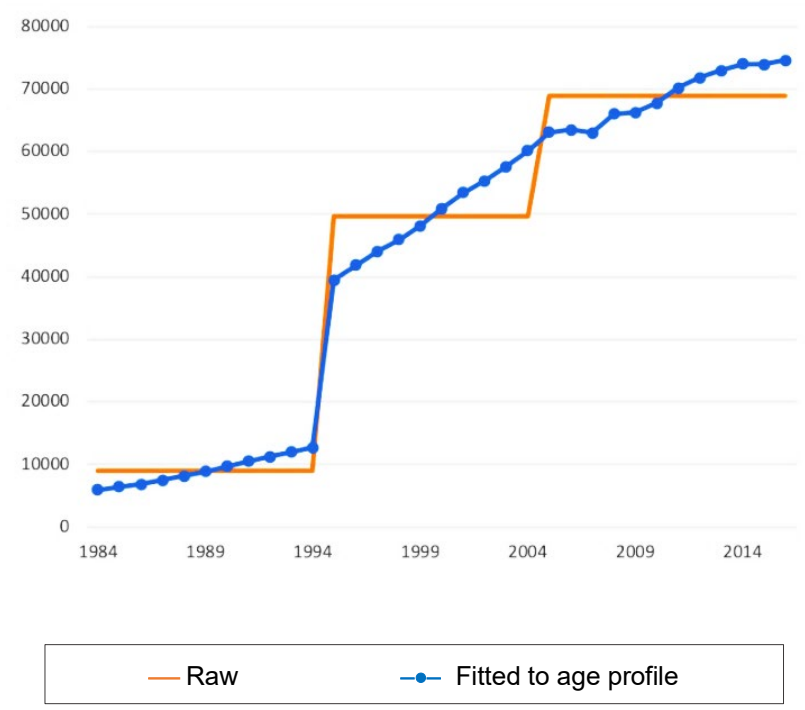

\section{A.2 Earnings forecasts}

The auxiliary sample used to estimate the earnings process consists of PSID respondents 30 and older, corresponding to waves 1990 to 2015 . Earnings from labor were deflated using the consumer price index, $\mathrm{CPI}-\mathrm{U}$, from the Bureau of Labor and Statistics.

We use this sample to estimate the following earnings process for the logarithm of real labor earnings:

$$
\log y_{t}^{i}=\alpha+X_{t}^{i} \beta+\tilde{X}_{t}^{i} x \gamma_{t}+\delta_{t}+\varepsilon_{t}^{i}
$$


where $X$ is a vector that includes a quadratic polynomial on age, marital status, gender, race and ethnicity, educational attainment, and work status. $\delta_{t}$ are time dummies. To allow the model to reflect any changes in labor market conditions for minorities, we interact linear trends, $\gamma_{t}$, with a female and a black dummy, $\tilde{X}_{t}^{i}$.

We use the coefficient estimated from this regression to forecast the future labor earnings of the UAS sample, from their survey participation until their expected retirement. For purposes of prediction, the year dummy is held constant at 2015 . To forecast future earnings growth, we follow the 2018 OASDI Trustees Report and assume a 1.17 percent annual real wage growth. ${ }^{13}$

\section{A.2.1 Earnings expectation bias}

We compare these forecasts to individual's own expected future earnings. We compute the average annual earnings bias, defined as the average of the difference between the subjective expected earnings and our forecast in each future year. Figure A.2 shows the histogram of the distribution of earnings expectation bias in our sample of nonretirees.

The average earnings expectation bias is $\$ 11,163$, and this bias is positive across subgroups, as shown in Table A.1. According to Table A.1, the earnings expectation bias does not differ significantly by gender, but it does differ by education -

\footnotetext{
${ }^{13}$ From the Economic Assumptions Section in the 2018 Annual Report of the Board of Trustees of the Federal Old-Age and Survivors Insurance and Federal Disability Insurance Trust Funds: "OCACT expects the ultimate average annual rate of change in the average OASDI covered wage to be approximately the same as for (1) average U.S. wages and (2) average U.S. earnings (which include the self-employed). The average annual real growth rate in average U.S. earnings is assumed to be $1.17 \%$ over the 65 -year period." Accessed online at: https://www.ssa.gov/OACT/TR/2018/2018_Long-Range_Economic_Assumptions.pdf
} 
with college workers showing a higher bias than those with lower educational attainment — and by marital status - married individuals have lower bias than individuals who are not married.

\section{Figure A.2: Distribution of earnings bias}

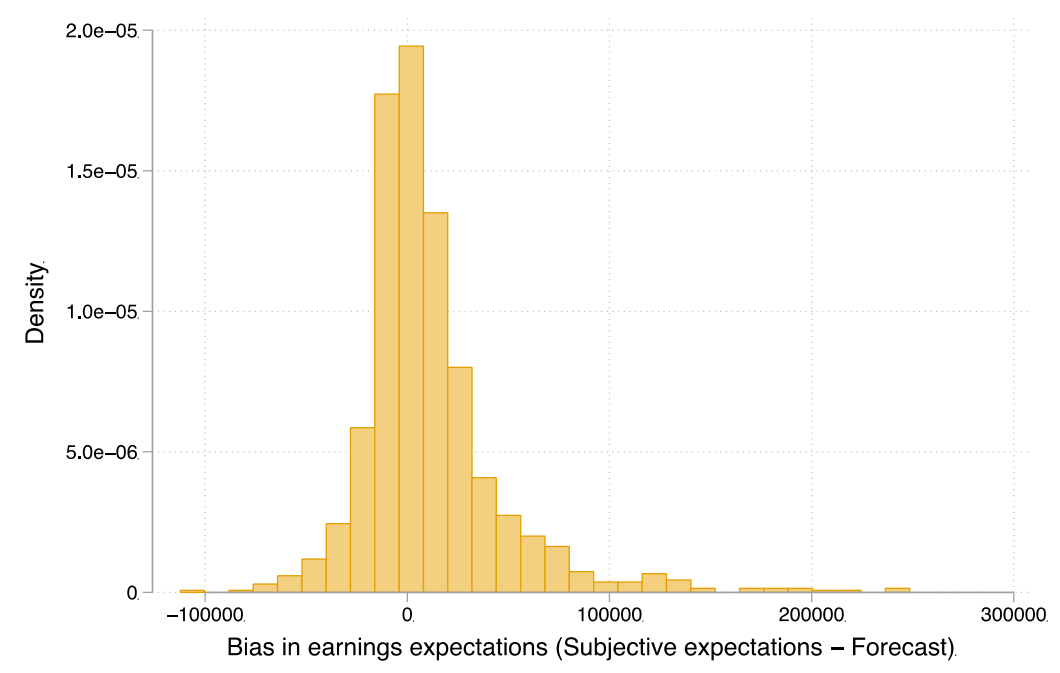

Note: Earnings expectation bias $=Y_{\text {subj }}^{\text {forec }} Y^{\text {forec }} P S I D$.

Table A.1: Average earnings expectation bias by subgroups

\begin{tabular}{|c|c|c|}
\hline & $\begin{array}{l}\text { Expectation bias } \\
\left(=Y^{\text {forec }} \text { subj }^{-} Y^{\text {forec }} \text { PSID }\right)\end{array}$ & $\begin{array}{l}95 \% \text { Confidence } \\
\text { interval }\end{array}$ \\
\hline Sample average & $11,163.7$ & {$[9,066.3,13,261.0]$} \\
\hline Female & $11,386.80$ & {$[8,878.6,13,895.1]$} \\
\hline Male & $10,901.10$ & {$[7,418.5,14,383.7]$} \\
\hline $\begin{array}{l}\text { Less than high } \\
\text { school }\end{array}$ & $3,080.70$ & {$[-2,505.7,8,667.2]$} \\
\hline High school & $7,956.20$ & {$[5,727.7,10,184.8]$} \\
\hline College & $15,169.20$ & {$[11,396.1,18,942.4]$} \\
\hline Not married & $13,722.50$ & {$[10,223.8,17,221.3]$} \\
\hline Married & $9,918.20$ & {$[7,310.8,12,525.5]$} \\
\hline
\end{tabular}

Note: Earnings bias is defined as the difference between expected annual earnings reported by respondents and earnings forecasts computed from PSID estimation. 


\section{A.3 Social Security retirement benefits calculation}

Using the sequence of past and predicted earnings, we follow these steps to forecast retirement benefits for the respondents in our survey: First, we adjust the earnings sequence to account for maximum taxable earnings. Social Security's OldAge, Survivors, and Disability Insurance program limits the amount of earnings subject to taxation for a given year. The same annual limit applies when those earnings are used in a benefit computation. ${ }^{14}$

Second, we index the sequence of earnings. The indexing factor equals one for the year in which the person attains age 60 and all later years. The indexing factor for a prior year $x$ is the result of dividing the average wage index for the year in which the person attains age 60 by the national average wage index for year $x .^{15}$

Third, we compute the average indexed monthly earnings (AIME) using the highest 35 years of indexed earnings. The basic Social Security benefit is called the primary insurance amount (PIA). The PIA is a function of AIME. The formula for this function depends on the year of first eligibility for retirement (the year a person attains age 62) and it is based on PIA formula bend points published by the Social Security Administration. ${ }^{16}$

Finally, the amount of retirement benefits a person will receive depends on their age when they begin claiming benefits. The benefits are adjusted depending on the person's age relative to the full retirement age. Benefits are subject to a discount if

\footnotetext{
14 This limit changes each year with changes in the national average wage index. The historical values of taxable maxima are available at: https://www.ssa.gov/OACT/COLA/cbb.html

${ }^{15}$ The National Average Wage Index Series is published by the Social Security Administration for every year since 1951.

${ }^{16}$ The Social Security website provides more information about the PIA formula: https://www.ssa.gov/oact/cola/piaformula.html
} 
taken before a person's normal (or full) retirement age and are increased if taken after normal retirement age.$^{17}$ Social Security also adjusts retirement benefits for inflation, which are cost-of-living adjustments.

\section{A.4 Model calibration}

We calibrate the model in a parsimonious way. We use standard parameter values when we can. These are the discount factor, $\beta$; the coefficient of relative risk aversion, $\gamma$; and the annual interest rate, $r$. The top panel of Table A.2 shows these standard parameter values. We use our survey data to obtain the parameter values related to individuals' expectations and forecasts of future earnings, shown in the bottom panel of Table A.2. We assume the same retirement age, $R$, for all individuals. This is also the age at which they start claiming retirement benefits. We set it equal to the current full retirement age.

Table A.2: Parameters used in the numerical solution and simulations of the model

\begin{tabular}{cll}
\hline \multicolumn{1}{c}{ Parameter } & Value \\
\hline $\boldsymbol{\beta}$ & \multicolumn{1}{c}{ Standard parameters } \\
$\boldsymbol{\gamma}$ & Discount factor & 0.98 \\
$\boldsymbol{r}$ & Coefficient of relative risk aversion & 1.5 \\
\hline Calibrated/estimated parameters & $1 \%$ \\
\hline $\boldsymbol{\rho}$ & Persistence of earnings process & 0.957 \\
$\boldsymbol{\sigma}$ & Standard deviation of innovation to earnings & 0.29 \\
$\boldsymbol{R}$ & Claiming and retirement age & 67 \\
$\boldsymbol{\rho}_{\boldsymbol{S u b j}}$ & Persistence of earnings process, subjective expectations & 0.92 \\
$\boldsymbol{\sigma}_{\boldsymbol{S u b j}}$ & Standard deviation of innovation to earnings, subjective & 0.37 \\
\hline
\end{tabular}

${ }^{17}$ Details about these adjustments available at: https://www.ssa.gov/planners/retire/applying1.html 